02 Royal Netherlands Institute for Sea Research

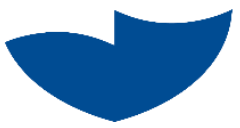

This is a postprint of:

Rush, D., Sinninghe Damsté, J.S., Poulton, S.W., Thamdrup, B., Leigh Garside, A., Acuña-Gonzalez, J., Schouten, S., Jetten, M.S.M. \& Talbot, H.M. (2014). Anaerobic ammonium-oxidising bacteria: A biological source of the bacteriohopanetetrol stereoisomer in marine sediments. Geochimica et Cosmochimica Acta, 140, 50-63

Published version: $\underline{\text { dx.doi.org/10.1016/i.gca.2014.05.014 }}$

Link NIOZ Repository: $\underline{w w w . v l i z . b e / n l / i m i s ? m o d u l e=r e f \& r e f i d=242287 ~}$

[Article begins on next page]

The NIOZ Repository gives free access to the digital collection of the work of the Royal Netherlands Institute for Sea Research. This archive is managed according to the principles of the Open Access Movement, and the Open Archive Initiative. Each publication should be cited to its original source - please use the reference as presented.

When using parts of, or whole publications in your own work, permission from the author(s) or copyright holder(s) is always needed. 


\section{Anaerobic ammonium-oxidising bacteria: A biological source of the bacteriohopanetetrol stereoisomer in marine sediments}

Darci Rush $^{1,2^{*}}$, Jaap S. Sinninghe Damsté ${ }^{2}$, Simon W. Poulton ${ }^{1,3}$, Bo Thamdrup ${ }^{4}$, A. Leigh Garside $^{1}$, Jenaro Acuña González ${ }^{5}$, Stefan Schouten ${ }^{2}$, Mike S.M. Jetten ${ }^{6}$, and Helen M. Talbot ${ }^{1}$

${ }^{1}$ Newcastle University, School of Civil Engineering \& Geosciences, Drummond Building, Newcastle upon Tyne, NE1 7RU, UK

${ }^{2}$ NIOZ Royal Netherlands Institute for Sea Research, Department of Marine Organic Biogeochemistry, P.O. Box 59, 1790 AB Den Burg, Texel, The Netherlands

${ }^{3}$ University of Leeds, School of Earth and Environment, Leeds, LS2 9JT, UK

${ }^{4}$ University of Southern Denmark, Department of Biology, Campusvej 55, DK-5230, Odense, Denmark

${ }^{5}$ University of Costa Rica, CIMAR and Escuela de Química, San José, Montes de Oca, San Pedro, 11501-2050, Costa Rica.

${ }^{6}$ Radboud University Nijmegen, Department of Microbiology, Heyendaalsweg 135, 6525 Nijmegen, The Netherlands

*corresponding author: darci.rush@newcastle.ac.uk Tel: +44 (0) 1912088501

Keywords:

anammox, bacteriohopanepolyols, bacteriohopanetetrol, BHT isomer, ladderane fatty acids, anoxic marine sediment, Golfo Dulce, Scalindua profunda, Kuenenia

stuttgartiensis 


\begin{abstract}
Bacterially-derived bacteriohopanepolyols (BHPs) are abundant, well preserved lipids in modern and paleo-environments. Bacteriohopanetetrol (BHT) is a ubiquitously produced BHP while its less common stereoisomer (BHT isomer) has previously been associated with anoxic environments; however, its biological source remained unknown. We investigated the occurrence of BHPs in Golfo Dulce, an anoxic marine fjord-like enclosure located in Costa Rica. The distribution of BHT isomer in four sediment cores and a surface sediment transect closely followed the distribution of ladderane fatty acids, unique biomarkers for bacteria performing anaerobic ammonium oxidation (anammox). This suggests that BHT isomer and ladderane lipids likely shared the same biological source in Golfo Dulce. This was supported by examining the BHP lipid compositions of two enrichment cultures of a marine anammox species ('Candidatus Scalindua profunda'), which were found to contain both BHT and BHT isomer. Remarkably, the BHT isomer was present in higher relative abundance than BHT. However, a non-marine anammox enrichment contained only BHT, which explains the infrequence of BHT isomer observations in terrestrial settings, and indicates that marine anammox bacteria are likely responsible for at least part of the environmentally-observed marine BHT isomer occurrences. Given the substantially greater residence time of BHPs in sediments, compared to ladderanes, BHT isomer is a potential biomarker for past anammox activity.
\end{abstract}




\section{INTRODUCTION}

Bacteriohopanepolyols (BHPs) are structurally diverse triterpenoids synthesised by a wide range of bacteria (although not all bacteria synthesise BHPs; e.g. Rohmer et al., 1984; Farrimond et al., 1998; Pearson et al., 2007), and likely have the same membrane-ordering role as sterols in eukaryotes (Kannenberg and Poralla, 1999; Sáenz et al., 2012). BHPs are the biological precursors of hopanoids, lipid biomarkers found ubiquitously in the geological record (Ourisson and Albrecht, 1992). Understanding the biological origin of specific BHPs and their associated environmental setting is crucial for deciphering the geohopanoid record and for reconstructing paleoenvironmental conditions (Zundel and Rohmer, 1985; Summons et al., 1999; Brocks and Pearson, 2005).

BHP specificity can range from broad to narrow. For example, BHPs can be ubiquitous (bacteriohopanetetrol [BHT, Fig. 1, I] is found in many bacterial cultures and environments), linked to particular environmental conditions (2-methyl and 3methyl hopanoids might be synthesised as a result of environmental stress; Doughty et al., 2009; Welander and Summons, 2012), or related to specific microbial processes (amino-BHPs, especially hexafunctionalised 35-aminobacteriohopanepentol, are synthesised by aerobic methane oxidisers; Cvejic et al., 2000; van Winden et al., 2012). Most described source organisms of BHPs have been aerobic bacteria, such as heterotrophs, methanotrophs, and cyanobacteria (Rohmer et al., 1984; Ourisson et al., 1987; Farrimond et al., 1998). However, there have been a few reports of BHPs, as well as the gene responsible for their cyclisation (squalene-hopene cyclase), occurring in anaerobic bacterial cultures (both obligate and facultative), including anaerobic ammonium oxidizing bacteria, sulfate-reducing bacteria and Geobacter sp. (Sinninghe Damsté et al., 2004; Fischer et al., 2005; Blumenberg et al., 2006; Rattray et al., 2008; Eickhoff et al., 2013).

Recently, Sáenz et al. (2011) reported a link between an isomer of bacteriohopanetetrol (BHT isomer; Fig. 1, II) and anoxic marine environments. Various designations have previously been used for this isomer [e.g. BHT II in Sáenz et al. (2011); BHT isomer 2 in Talbot et al., (2003c) and in Blumenberg et al. (2010)]. From here on, we will refer to this isomer as "BHT isomer". The stereoconfiguration of BHT was confirmed as $22 R, 32 R, 33 R, 34 S$ (Bisseret and Rohmer, 1989). However, as BHT isomer has not yet been isolated, the exact stereochemistry of this particular BHT is undetermined. Certain possibilities can be nevertheless ruled out. The close 
relative retention times of $\mathrm{BHT}$ and $\mathrm{BHT}$ isomer excludes the much earlier eluting $17 \alpha, 21 \beta(H)$-BHT configuration (Talbot et al., 2008a). Moreover, in sediments underlying the Benguela Upwelling system, which were shown to contain significant amounts of BHT isomer, the predominant (98\%) bishomohopanol (the resulting hopanol after periodic acid treatment of a tetrafunctionalised BHP) configuration was $22 R-17 \beta, 21 \beta(H)$, indicating a likely "biological" configuration of the hopanoid ring system for BHT isomer (Blumenberg et al., 2010). Consequently, the likely difference between BHT and BHT isomer occurs on the chain, which would not be apparent after periodic acid treatment. BHT isomer stereochemistry could differ from BHT at the C-34 position (i.e. $22 R, 32 R, 33 R, 34 R$ [Fig. 1, II]). This particular BHT stereochemistry was identified by nuclear magnetic resonance (NMR) in species of acetic acid bacteria (Acetobacter pasteurianus and A. aceti ssp. xylinum, which has since been reclassified as A. pasteurianus) containing BHT and a BHT isomer (Peiseler and Rohmer, 1992). However, until the exact stereochemistry of the marine BHT isomer is determined, we cannot disregard other possibilities. The $22 R, 32 R$, $33 R, 34 R$ configuration (II) of BHT has also been reported in approx. 1:1 mixture with the $22 R, 32 R, 33 R, 34 S$ configuration (I) in a Frankia sp., a terrestrial nitrogenfixing plant symbiont (Rosa-Putra et al., 2001). In addition to Frankia sp. and Acetobacter sp., an aerobic Type II methanotrophic bacteria (Methylocella palustris ${ }^{l}$ ) isolated from a peat bog (van Winden et al., 2012) was shown to synthesise small amounts of BHT isomer.

However, so far the major biological source organism in marine environments, where BHT isomer is most often detected (Blumenberg et la., 2010; Sáenz et al., 2011; Wakeham et al., 2012; Berndmeyer et al., 2013; Kharbush et al., 2013), remains unknown. Sáenz et al. (2011) hypothesised that an anaerobic organism is responsible for the synthesis of the marine occurrences of BHT isomer.

A study of the water column of the anoxic, sulfidic Cariaco Basin by Wakeham et al. (2012) revealed that the peak concentration of BHT isomer occurred at the chemocline, comparable to the peak in ladderane fatty acid concentrations. Ladderane lipids are synthesised uniquely by anaerobic ammonium oxidising (anammox) bacteria (Fig. 1, III - VI; Sinninghe Damsté et al., 2002), and are used as biomarkers

\footnotetext{
${ }^{1} \mathrm{~A}$ Methylomonas-like strain of bacteria was incorrectly identified as synthesising BHT isomer by van Winden et al., (2012). Upon re-examination of the original chromatograms, we have concluded that in fact Methylocella palustris synthesizes BHT isomer.
} 
for the anammox reaction in environmental systems (Kuypers et al., 2003; Hamersley et al., 2007; Jaeschke et al., 2009; Rush et al., 2012a). Since its first identification in the environment (Thamdrup and Dalsgaard, 2002), anaerobic ammonium oxidation has been found to be an important pathway in the marine nitrogen cycle, and the reaction is performed exclusively by bacteria referred to as anammox bacteria. Anammox bacteria are a deep-branching phylogenetic group (Strous et al., 2006), members of the order Brocadiales (Phylum Planctomycetes), and probably played a major role in ammonium oxidation in ancient environments. For example, it has been suggested that the anammox process was partly responsible for massive sinks in marine bioavailable nitrogen during widespread marine anoxia (Ocean Anoxic Events; OAEs) in the Cretaceous (Kuypers et al., 2004). However, diagnostic ladderane lipids contain concatenated cyclobutane rings and are susceptible to both microbial degradation (Rush et al., 2011) and thermal alternations (Jaeschke et al., 2008) during burial, making ladderane fatty acids improbable tracers for anammox in ancient environments.

A study by Sinninghe Damsté et al. (2004), based on GC-MS analyses of five anammox enrichment cultures (in which strains of 'Candidatus Brocadia anammoxidans', 'Ca. Kuenenia stuttgartiensis', 'Ca. Scalindua brodae', and ' $C a$. Scalindua wagneri' comprised $20-80 \%$ of the biomass), found that anammox bacteria also contain hopanoids, including BHT. Subsequently, BHT was also identified by way of GC-MS in another enrichment ( $\pm 75 \%$ purity) of marine anammox bacterium, 'Ca. Scalindua sp.' (Rattray et al., 2008). Squalene-hopene cyclase was detected in the genome of ' $\mathrm{Ca}$. Kuenenia stuttgartiensis' by Strous et al. (2006) and Pearson et al., (2007), and in the genome of ' $C a$. Scalindua profunda' by van de Vossenberg et al. (2013). Thus, anammox bacteria are capable of synthesising hopanoids, including BHT, in anoxic environments.

We have analysed sediments from Golfo Dulce, an anoxic, non-sulfidic fjordlike enclosure located on the Pacific coast of Costa Rica. Anammox activity and bacteria have been reported in the Golfo Dulce water column and sediments (Dalsgaard et al., 2003; Schmid et al., 2007). Due to its geochemical conditions (i.e. very low sulfide concentrations, nitrate-rich water, anoxic basin; Ferdelman et al., 2006), Golfo Dulce is an ideal location to study (bio)geochemical interactions under redox conditions that may have been extensive during past periods of Earth's history, and are representative of oceanic oxygen minimum zones. Here, we focused on BHPs 
(specifically BHT and its isomer) and the link between ladderane fatty acids in Golfo Dulce in order to potentially establish an appropriate biomarker for anammox bacteria that would expand the tracing of this nitrogen cycle process to ancient environments. This environmental study was complemented with BHP studies on highly enriched anammox cultures.

\section{MATERIAL AND METHODS}

\subsection{Samples}

\subsubsection{Golfo Dulce sediments}

Golfo Dulce is $200 \mathrm{~m}$ deep and is physically cut off from mixing with the Pacific Ocean by a sill at $60 \mathrm{~m}$ depth, which promotes anoxic water column conditions within the basin. Previous studies by Richards et al. (1971) and Ferdelman et al. (2006) reported three distinct chemical zones in the Golfo Dulce water column (Fig. 2): 1) an oxic zone (surface to $40 \mathrm{~m})$; 2) a transitional zone, (40 - $110 \mathrm{~m}$ ); and 3) a nitrogenous zone [i.e. anoxic and containing nitrate and nitrite as most favourable electron acceptors (Canfield and Thamdrup, 2009); below ca. $110 \mathrm{~m}$ ]. Apart from a few meters above the sediment surface, where low concentrations of sulfide may occur in the deep basin, Golfo Dulce anoxic water is non-sulfidic (Ferdelman et al., 2006). Nitrate reduction was observed in the anoxic water column, where ammonium was not seen to accumulate, indicating the presence of the anammox process, which has been confirmed by nitrogen-labelling experiments (Dalsgaard et al., 2003).

Sediment samples were collected in March 2008. Grab samples (comprising the upper few $\mathrm{cm}$ of sediment) across a basinal transect incorporated the three chemical zones, and were collected from $10-140 \mathrm{~m}$ water depth (Fig. 2). Additionally, four short sediment cores were collected (one from the oxic zone, one from the oxic-nitrogenous transition zone, and two from the anoxic zone) with a gravity corer. Soon after sampling (within $2 \mathrm{~h}$ ), the cores were sub-sampled under a nitrogen atmosphere at $2 \mathrm{~cm}$ intervals, down to $26-54 \mathrm{~cm}$ (Fig. 3). Collected sediments were then immediately frozen, and were subsequently freeze-dried prior to analysis. Golfo Dulce oxygen concentrations were measured in near-bottom water samples retrieved along the sediment surface transect in a Niskin bottle at water depths of $2,12,19,35,50,65,80,120$ and $170 \mathrm{~m}$. Measurement were performed 
according to the Winkler method (Grasshoff, 1983), with a detection limit of $5-10$ $\mu \mathrm{M}$.

\subsubsection{Anammox cultures and enrichment}

Two enrichment cultures of ' $\mathrm{Ca}$. Scalindua profunda' were grown in sequencing batch reactors at different temperatures $\left(15\right.$ and $\left.23{ }^{\circ} \mathrm{C}\right)$ for over two years as described in van de Vossenberg et al. (2008). Previous microscopic analysis of these enrichments showed S. profunda comprised $80-90 \%$ of the cells, while other bacteria belonging to the phyla Bacteriodetes (including Flavobacteriaceae) and Proteobacteria (including Alphaproteobacteria) accounted for the majority of the remaining populations (van de Vossenberg et al., 2008; 2013).

Sludge was obtained from a Dutch waste water treatment pilot plant that was using the anammox process (Paques B.V., Balk, The Netherlands). This sludge contained $70 \%$ bacterial dominance of ' $\mathrm{Ca}$. Kuenenia stuttgartiensis' (Schmid et al., 2000; Boumann et al., 2006).

\subsection{Lipid extraction}

\subsubsection{Golfo Dulce sediment extraction}

The freeze-dried sediments $(0.2-5.6 \mathrm{~g})$ were extracted 4 times for $5 \mathrm{~min}$ by an accelerated solvent extractor (ASE 200, DIONEX) using a solvent mixture of DCM:MeOH (3:1) at relatively low temperature $\left(40^{\circ} \mathrm{C}\right)$ and medium pressure $(6.9$ MPa), as described by Rush et al. (2012b). The obtained TLEs were dried using a Turbo Vap LV (Caliper Life Sciences), and stored at $4{ }^{\circ} \mathrm{C}$.

\subsubsection{Anammox biomass extraction}

Cells were extracted using a modified Bligh-Dyer method (Bligh and Dyer, 1959; Cooke et al., 2008). Briefly, freeze-dried material $(<20 \mathrm{mg}$ for bacterial cell material from culture, and $1 \mathrm{~g}$ for ' $\mathrm{Ca}$. Kuenenia stuttgartiensis' sludge from Dokhaven wastewater treatment plant) was extracted in a Teflon tube with $19 \mathrm{~mL}$ of a 4:10:5 (v:v:v) mixture of $\mathrm{H}_{2} \mathrm{O}: \mathrm{MeOH}$ :chloroform. This mixture was sonicated at $40^{\circ} \mathrm{C}$ for 15 min, and centrifuged for $10 \mathrm{~min}$. The supernatant was transferred to a second Teflon tube, and the residue re-extracted twice more. The chloroform in the supernatant was separated from the aqueous phase by adding water until the $\mathrm{H}_{2} \mathrm{O}: \mathrm{MeOH}$ ratio was $1: 1$ (v:v), and collected. This procedure was repeated for the subsequent extractions. The collected chloroform was dried by rotary evaporation in a round-bottom flask. 


\subsection{Lipid analyses}

\subsubsection{BHP preparation and HPLC/APCI-MS $S^{n}$ analyses}

A known amount of internal standard ( $5 \alpha$-pregnane-3 $\beta, 20 \beta$-diol) was added to aliquots of the extracts for BHP analysis. Samples were acetylated in $0.5 \mathrm{~mL}$ of a $1: 1$ (v:v) mixture of acetic anhydride and pyridine at $50{ }^{\circ} \mathrm{C}$ for $1 \mathrm{~h}$, then overnight at room temperature. Solvent was dried under a stream of $\mathrm{N}_{2}$ on a $50^{\circ} \mathrm{C}$ heating block. BHPs samples were dissolved in MeOH:propan-2-ol (3:2; v:v), and filtered on $0.2 \mu \mathrm{m}$ PTFE filters.

BHPs were analysed by high performance liquid chromatography coupled to positive ion atmospheric pressure chemical ionization mass spectrometry (HPLC/APCI-MS), using a data-dependent scan mode (3 events) on an HPLC system equipped with an ion trap MS, as described in Talbot et al. (2007) and van Winden et al. (2012). BHT and BHT isomer (Fig. 1, I and II) concentrations were (semi) quantitatively estimated based on the response factor of authentic peracetylated BHT standard (M. Rohmer; Strasbourg, France; Cooke et al., 2008) relative to the internal standard. Reproducibility was $\pm 20 \%$, according to Cooke et al. (2010). BHT and BHT isomer concentrations in Golfo Dulce sediment samples were expressed in $\mu \mathrm{g}$. $\mathrm{g}^{-1}$ TOC.

\subsubsection{Ladderane fatty acid preparation and HPLC/APCI-MS/MS analyses}

Aliquots of the TLEs were saponified by refluxing with aqueous $\mathrm{KOH}$ (in $96 \% \mathrm{MeOH})$ for $1 \mathrm{~h}$. Fatty acids were obtained by acidifying the saponified samples to pH 3 with $1 \mathrm{~N} \mathrm{HCl}$ in $\mathrm{MeOH}$, and extracted using DCM. The fatty acids were converted to their corresponding fatty acid methyl esters (FAMEs) by methylation with diazomethane $\left(\mathrm{CH}_{2} \mathrm{~N}_{2}\right)$. Polyunsaturated fatty acids were removed by eluting the sample over a small $\mathrm{AgNO}_{3}$ impregnated (5\%) silica column with DCM. The fatty acid fractions were dissolved in acetone, and filtered through $0.45 \mu \mathrm{m}, 4 \mathrm{~mm}$ diameter PTFE filters.

Ladderane fatty acids were analysed by high performance liquid chromatography coupled to positive ion atmospheric pressure chemical ionization tandem mass spectrometry (HPLC/APCI-MS/MS) in selective reaction monitoring mode as originally described in Hopmans et al. (2006) and expanded in Rush et al. (2011). Four ladderane FAMEs $\left(\mathrm{C}_{18}\right.$-[3]-ladderane fatty acid, $\mathrm{C}_{18}$-[5]-ladderane fatty acid, $\mathrm{C}_{20}$-[3]-ladderane fatty acid, and $\mathrm{C}_{20}$-[5]-ladderane fatty acid; Fig. 1, IV - VII) were quantified using external calibration curves of two standards of isolated 
methylated ladderane fatty acids $\mathrm{C}_{20}$-[3]-ladderane fatty acid, and $\mathrm{C}_{20}$-[5]-ladderane fatty acid (Hopmans et al., 2006; Rattray et al., 2008). Two additional short-chain ladderane fatty acids $\left(\mathrm{C}_{14}\right.$-[3]-ladderane fatty acid and $\mathrm{C}_{14}$-[5]-ladderane fatty acid) were analysed in the Golfo Dulce sediment cores, and were quantified using an external calibration curve of $\mathrm{C}_{14}$-[3]-ladderane fatty acid (Rush et al., 2011). A detection limit of 30-35 pg was achieved with this technique. The analytical reproducibility of ladderane fatty acid concentrations based on duplicate analysis was $>8 \%$. Ladderane fatty acid concentrations in Golfo Dulce sediment samples were expressed in $\mu \mathrm{g} \cdot \mathrm{g}^{-1}$ TOC.

\subsubsection{NL}

The $\mathrm{NL}_{5}$ (iNdex of Ladderane lipids with $\underline{5}$ cyclobutane rings) is based on the observation that the relative length of the ladderane alkyl side chain adapts to variations in growth temperature of the anammox bacteria in cultures and the natural environment (Rattray et al., 2010). NL5 temperatures, as a means to determine the origin of the ladderane fatty acids, were calculated in the Golfo Dulce sediment cores, according to the equations of Rattray et al. (2010).

$$
\begin{aligned}
& \mathrm{NL}_{5}=\frac{\mathrm{C}_{20} \text {-[5]-ladderane fatty acid }}{\left(\mathrm{C}_{18}-[5] \text {-ladderane fatty acid }+\mathrm{C}_{20}-[5] \text {-ladderane fatty acid }\right)} \\
& \mathrm{NL}_{5}=0.2+\frac{0.7}{1+\left(\frac{\text { Temperature-16.3 }}{1.5}\right)}
\end{aligned}
$$

\section{RESULTS}

\subsection{Golfo Dulce surface sediments}

BHP and ladderane fatty acid concentrations were measured along a sediment surface transect that spanned the three chemical zones in Golfo Dulce $(10-140 \mathrm{~m}$ water depth; Fig. 2). Oxygen concentrations across this transect dropped from $412 \mu \mathrm{M}$ at $2 \mathrm{~m}$ water depth, to below detection limit $(5-10 \mu \mathrm{M})$ at water depths $>50 \mathrm{~m}$.

BHT concentration in surface sediments increased from $30 \mu \mathrm{g} \cdot \mathrm{g}^{-1}$ TOC at $10 \mathrm{~m}$ to $210 \mu \mathrm{g} \cdot \mathrm{g}^{-1}$ TOC at $24 \mathrm{~m}$ (Fig. 2) then decreased gradually down the transect (to $100 \mu \mathrm{g} \cdot \mathrm{g}^{-1}$ TOC at $140 \mathrm{~m}$ ), with the exception of $120 \mathrm{~m}$, where BHT concentration was the highest ( $300 \mu \mathrm{g} \cdot \mathrm{g}^{-1}$ TOC, respectively). Most occurrences of BHT isomer in 
the Golfo Dulce surface transect occurred in and below Zone 2, the oxic-nitrogenous transition zone (i.e. $>70 \mathrm{~m}$ water depth; $4.0-38 \mu \mathrm{g} \cdot \mathrm{g}^{-1}$ TOC; Fig. 2), with the highest concentration at $120 \mathrm{~m}$ depth $\left(38 \mu \mathrm{g} \cdot \mathrm{g}^{-1}\right.$ TOC), matching the peak in BHT concentration. BHT isomer was also observed in the shallowest surface sediment, albeit in low concentration $\left(0.7 \mu \mathrm{g} \cdot \mathrm{g}^{-1} \mathrm{TOC}\right)$.

Like the BHT isomer profile, the concentration of ladderane fatty acids increased with increasing water depth (Fig. 2). The highest concentration of ladderanes occurred in the anoxic zone $\left(5.2 \mu \mathrm{g} \cdot \mathrm{g}^{-1}\right.$ TOC; $120 \mathrm{~m}$ water depth), which coincided with the highest concentrations of BHT and BHT isomer. Ladderanes were present at low concentration in the shallowest surface sediment $\left(0.2 \mu \mathrm{g} \cdot \mathrm{g}^{-1} \mathrm{TOC} ; 10 \mathrm{~m}\right)$.

\subsection{Golfo Dulce sediment cores}

Core 2C was located at $15 \mathrm{~m}$ water depth (Fig. 3a), in Zone 1, where oxygen concentrations in the water column were high (>250 $\mu$ M: Fig. 2). BHT concentration in this core varied with sediment depth (fluctuating between $27-310 \mu \mathrm{g} \cdot \mathrm{g}^{-1}$ TOC). BHT isomer was only present in one sample in Core $2 \mathrm{C}$ (at $24-26 \mathrm{cmbsf}$ ), and in low concentration $\left(0.7 \mu \mathrm{g} \cdot \mathrm{g}^{-1}\right.$ TOC $)$. Ladderane fatty acids were not detected.

Core 6A (40 m water depth; Fig. 3b) was located at the upper boundary of Zone 2. BHT concentration at the top of this core was $84 \mu \mathrm{g} \cdot \mathrm{g}^{-1} \mathrm{TOC}$, and fluctuated between a maximum of $220 \mu \mathrm{g} \cdot \mathrm{g}^{-1}$ TOC at $2-4 \mathrm{cmbsf}$ and a minimum of $12 \mu \mathrm{g} \cdot \mathrm{g}^{-1}$ TOC at the bottom of the core $(42-44 \mathrm{cmbsf})$. BHT isomer and ladderane fatty acids were detected at low concentration $\left(0.0-6.6 \mu \mathrm{g}\right.$ BHT isomer $\cdot \mathrm{g}^{-1}$ TOC and $0.0-0.7 \mu \mathrm{g}$ ladderane fatty acids $\cdot \mathrm{g}^{-1}$ TOC) throughout most of this core $(0-37 \mathrm{cmbsf})$, though not necessarily at the same depths. However, a significant peak in ladderane fatty acid concentration was observed at the bottom of Core 6A $\left(7.7\right.$ and $8.2 \mu \mathrm{g} \cdot \mathrm{g}^{-1}$ TOC, between 37 and $44 \mathrm{cmbsf}$ ), which did not coincide with BHT isomer concentration.

The peak concentration of BHT in Core 4A (Zone 3, 182 - $185 \mathrm{~m}$ water depth; Fig. 3c) occurred at the top of the core $\left(380 \mu \mathrm{g} \cdot \mathrm{g}^{-1}\right.$ TOC; $\left.0-2 \mathrm{cmbsf}\right)$. A secondary peak in BHT (360 $\mu \mathrm{g} \cdot \mathrm{g}^{-1}$ TOC) occurred at $32-34 \mathrm{cmbsf}$, and a smaller peak occurred at $17-19 \mathrm{mbsf}\left(220 \mu \mathrm{g} \cdot \mathrm{g}^{-1}\right.$ TOC). Concentrations of BHT isomer and ladderane fatty acids were substantially higher than in the cores from Zones 1 and 2, and both lipids were observed throughout the core. Peaks in BHT isomer occurred at 0 $-2 \mathrm{cmbsf}\left(97 \mu \mathrm{g} \cdot \mathrm{g}^{-1}\right.$ TOC), $17-19\left(50 \mu \mathrm{g} \cdot \mathrm{g}^{-1}\right.$ TOC), and $32-34 \mathrm{cmbsf}(180 \mu \mathrm{g} \cdot$ 
$\mathrm{g}^{-1}$ TOC). Ladderane fatty acids peaked at the same depths as BHT isomer, with concentrations of $10,2.9$, and $2.7 \mu \mathrm{g} \cdot \mathrm{g}^{-1}$ TOC, respectively.

The highest concentration of BHT was observed as a subsurface peak in the deepest core, Core 3B (190 mbsf; Fig. 3d). BHT concentration at $17-19 \mathrm{cmbsf}$ was $560 \mu \mathrm{g} \cdot \mathrm{g}^{-1}$ TOC. BHT concentrations were also high at the top $\left(400 \mu \mathrm{g} \cdot \mathrm{g}^{-1}\right.$ TOC; 0 $2 \mathrm{cmbsf})$ and bottom (220 $\mu \mathrm{g} \cdot \mathrm{g}^{-1}$ TOC; $\left.52-54 \mathrm{cmbsf}\right)$ of Core $3 \mathrm{~B}$. The maximum in BHT isomer concentration was also at $17-19 \mathrm{cmbsf}\left(180 \mu \mathrm{g} \cdot \mathrm{g}^{-1} \mathrm{TOC}\right)$. Ladderane fatty acid concentration was highest $\left(8.5 \mu \mathrm{g} \cdot \mathrm{g}^{-1}\right.$ TOC) at the surface $(0-2 \mathrm{cmbsf})$ of core 3B. However, ladderanes also peaked $\left(4.5 \mu \mathrm{g} \cdot \mathrm{g}^{-1}\right.$ TOC) at $17-19 \mathrm{cmbsf}$. The BHT isomer distribution in the samples of Core 3B that were analysed followed the same pattern as the distribution of ladderane fatty acids.

\subsection{BHPs in anammox cultures}

In this study, three samples of cell material from two different anammox species were analysed for BHPs. Two enrichment cultures were of the marine species ' $\mathrm{Ca}$. Scalindua profunda', grown at different temperatures $\left(15\right.$ and $23^{\circ} \mathrm{C}$, Figs. $4 \mathrm{a}$ and $4 \mathrm{~b}$, respectively). The third sample was sludge from a waste water pilot plant, where the non-marine anammox species ' $\mathrm{Ca}$. Kuenenia stuttgartiensis' formed the majority of the microbial community (Fig. 4c).

All three anammox samples contained BHPs, including BHT (Fig. 4). BHT isomer was observed in high relative abundances in the two marine Scalindua cultures (Figs. 4a and 4b). The most abundant BHP in the non-marine anammox was the composite BHP (i.e. a BHP with a more complex functional group, such as a sugar, at the terminal C-35 position), BHT cyclitol ether (Fig. 4c; III, Fig. 1). A small shoulder of BHT might be observed in K. stuttgartiensis (Fig. 4c), and potentially could be attributed to BHT isomer. Nevertheless, this possible peak of BHT isomer would only account for $1 \%$ of total BHPs in K. stuttgartiensis.

BHT isomer was observed in higher relative abundance than BHT in the ' $C a$. S. profunda' cultures (Figs. 4a and 4b), and was the most abundant BHP in both marine culture enrichments. BHT cyclitol ether was also observed in these Scalindua enrichments, but in smaller abundance than in the Kuenenia sludge.

Screening of the marine anammox biomass for BHPs also revealed two unknown earlier-eluting components with parent ions of $m / z 880$ and $m / z 894$ (Figs. 4a and 4b). 
$\mathrm{MS}^{2}$ revealed that both parent ions fragmented into the characteristic acetylated BHT fragment $m / z 655$ (Fig. 5). $\mathrm{MS}^{3}$ showed the distinctive fragments $(\mathrm{m} / \mathrm{z}$ 191, 283, 463, 475, 535, and 595) of acetylated BHT (cf. Talbot et al., 2003a). This confirms these are tetrafunctionalised BHPs associated with a composite terminal group ( $\mathrm{T}^{+}$of $m / z$ 226 or 240). Each composite group likely contains an odd number of nitrogen ions, due to the even mass/charge ratio of the parent ions (cf. BHT cyclitol ether; Fig. 1, III; Talbot et al., 2003b). The two BHPs probably vary by a $\mathrm{CH}_{2}$ group in the terminal group, as their masses $(\mathrm{m} / \mathrm{z} 880$ and 894$)$ differ by $14 \mathrm{Da}$. The BHP with a parent ion of $m / z 894$ was only found in the ' $\mathrm{Ca}$. S. profunda' culture grown at $15^{\circ} \mathrm{C}$ (Fig. 4).

\section{DISCUSSION}

\subsection{Co-occurrence of anammox communities and BHT isomer in Golfo Dulce}

Throughout the Golfo Dulce sediments, BHT isomer and ladderane fatty acids followed a similar trend in their concentrations. This was especially true for the surface sediments. When plotted against each other, the concentration of BHT isomer versus the concentration of ladderanes in surface sediments showed a strong correlation $\left(\mathrm{R}^{2}=0.97, \mathrm{p}<0.01\right.$; Fig. 6a), suggesting the same organism may be responsible for the biosynthesis of BHT isomer and ladderane fatty acids. As anammox bacteria are the only known source organisms of ladderanes (Sinninghe Damsté et al., 2002), it is likely that BHT isomer is synthesised by anammox bacteria, at least in this setting.

For the most part, the concentrations of BHT isomer and ladderane fatty acids also correlated in the sediments from the deeper cores, though not as strongly (Fig. 6b,

$\mathrm{R}^{2}=0.54, \mathrm{p}<0.01$; solid line). The concentrations of lipids in these sediments are probably affected by differential degradation rates of the BHPs versus ladderane fatty acids. In both Cores 4A and 3B (Fig. 3c and 3d), the concentration of ladderane fatty acids was highest at the top of the core and decreased substantially down core, whereas the highest concentration of BHT isomer occurred subsurface. A relative decrease in ladderane concentration with depth has been observed previously in sediments where degradation is a likely process (Rush et al., 2012b). These results indicate a preferential degradation of ladderanes versus BHT isomer, and may explain why the correlation between the two lipid types is not as strong with depth as it is at surface (Fig. 6a). The plot of BHT isomer versus ladderanes in deeper sediment (Fig. 
6b) may show two different correlations: one representing the sediments from the bottom of the cores (3B and 4A, below $22 \mathrm{cmbsf}$; $6 \mathrm{~A}$, below $8 \mathrm{cmbsf}$ ) that are affected by preferential degradation (dashed line; $\mathrm{R}^{2}=0.91, \mathrm{p}<0.01$ ); and one representing the shallower sediments that are unaffected by preferential degradation (dotted line; $\mathrm{R}^{2}=0.88, \mathrm{p}<0.01$ ). The difference in sediment depth cut-off for preferential degradation between the shallow core (6A; $8 \mathrm{cmbsf})$ and deeper cores $(4 \mathrm{~A}$ and 3B; $22 \mathrm{cmbsf}$ ) may be due to the deeper cores in Golfo Dulce basin having higher accumulation rates (Hebbeln et al., 1996) whilst the shallow core in the transition zone may be more readily affect by $\beta$-oxidation of ladderane fatty acids (Rush et al., 2011). This also reveals the potential worth of using BHT isomer in place of ladderane fatty acids as biomarkers for anammox in sediments from ancient environments.

The peaks and troughs observed in BHT isomer and ladderane fatty acids concentrations in the Golfo Dulce sediment cores (Fig. 3) probably reflect changes in the flux of anammox lipids to the sediment surface relative to bulk sediment deposition. This could be due to shifts in nutrient availability for anammox bacteria, but also to dilution or concentration of anammox biomass resulting from mass deposition of sediment originating from shallower depths in turbiditic events. Such events can be responsible for sediment layers of up to $10 \mathrm{~cm}$ thickness with upward fining sequences in the deep basin, and were suggested to explain visual $\mathrm{cm}$-scale layering of the sediment on the slope (Hebbeln et al., 1996; Thamdrup et al., 1996).

There was, however, an exception to the general correlation of BHT isomer and ladderane fatty acid concentrations (Fig. 6b). A clear peak in ladderane fatty acids was observed at the bottom of Core 6A (Fig. 3b), which was not reflected in the BHT isomer concentration profile. This core was located at the upper boundary of the oxicnitrogenous transition zone (Zone 2), and it is likely that this setting is highly susceptible to minor shifts in the location of the redoxcline. This peak in ladderanes probably represents production by sedimentary anammox bacteria, as there was no detection of short-chain ladderane fatty acids at these depths (Fig. 7b). Short-chain ladderane fatty acids are produced when ladderane fatty acids, which have been synthesised in oxygen-depleted environments, are exposed to $\beta$-oxidation (Rush et al., 2011). As only low levels of oxygen $(<3 \mu \mathrm{M})$ are needed for the oxidation pathway to proceed (Rush et al., 2012b), short-chain ladderanes have been used previously as biomarkers for the microbial degradation of anammox bacterial lipids in low oxygen 
environments. However, short-chain ladderanes have not been detected in anoxic environments (e.g. the Cariaco Basin, Rush et al., 2012b). The lack of short chain ladderanes at these two depths in Core 6A (Fig. 7) indicates that these ladderane fatty acids were neither synthesised in oxygen concentrations above $3 \mu \mathrm{M}$, nor exposed to oxic conditions afterwards.

In contrast to the bottom of Core $6 \mathrm{~A}$, short-chain ladderane fatty acids were detected alongside ladderane fatty acids at all depths in the deeper, anoxic cores (cores 4A and 3B; Fig. 7), usually in even higher concentration than the original ladderane fatty acids $\left(0.4-15 \mu \mathrm{g}\right.$ short-chain ladderane fatty acids $\cdot \mathrm{g}^{-1} \mathrm{TOC}$ in Core $4 \mathrm{~A} ; 0.9-12 \mu \mathrm{g}$ short-chain ladderane fatty acids $\cdot \mathrm{g}^{-1}$ TOC in Core $\left.3 \mathrm{~B}\right)$. This indicates that the ladderane fatty acids detected in these cores were probably produced at the oxycline, where oxygen was depleted enough for anammox to be active, but still present in high enough concentration for the $\beta$-oxidation to occur. It is therefore likely that the ladderane fatty acids in Cores $4 \mathrm{~A}$ and $3 \mathrm{~B}$ were produced in the water column, while the peak in ladderanes at the bottom of core $6 \mathrm{~A}$ represents production in the (transitionally) anoxic sediment. Using nitrogen-labelling experiments, Dalsgaard et al. (2003) found anammox to be a significant process in Zone 3 of the Golfo Dulce water column. However, they did not detect any labelling evidence of anammox activity in the water column of Zone 2, while Schmid et al. (2007) found anammox activity in surface sediment in Zone 2 (at $55 \mathrm{~m}$ water depth), which further supports in situ benthic production as the origin of the ladderane fatty acid peak at depth in Core 6A. Nevertheless, this peak probably does not represent in situ production at $37-44$ cmbsf, but rather surface activity by a sedimentary anammox community that was rapidly buried by a recent mass deposition or turbiditic event. Though NL5 temperature data, derived from the ratio of $\mathrm{C}_{20}$ and $\mathrm{C}_{18}$ ladderane fatty acids with five cyclobutane rings (Rattray et al., 2010), does not always correlate with absolute temperature values (Rush et al., 2012a), it can be used to compare anammox growth environments within the same core. $\mathrm{NL}_{5}$ temperatures in Golfo Dulce (Fig. 7) show a lower growth temperature for anammox producing ladderane fatty acids at the bottom of Core $6 \mathrm{~A}\left(14^{\circ} \mathrm{C}\right)$ compared with the rest of the core $\left(16-19^{\circ} \mathrm{C}\right)$, which is consistent with an exogenous sedimentary origin of this deep ladderane peak. Thus, it is possible that sedimentary anammox bacteria have adapted differently than pelagic bacteria and do not produce BHT isomer, and that BHT isomer in marine sediments indicates pelagic anammox activity. However, as the exact function of BHT isomer in 
the cell is unknown, we cannot hypothesise further as to why there might be a difference between sedimentary and pelagic anammox BHP compositions.

Like BHT isomer, the concentration of BHT followed a similar trend as that of ladderane fatty acids, when both these lipids were present. However, BHT was also present when ladderanes were not detected. This suggests that the organism responsible for synthesising ladderane fatty acids is likely also biosynthesising BHT, but that it is not the exclusive source organism for BHT. Indeed, BHT has been observed in multiple bacterial cultures (e.g. Talbot et al., 2008b), whereas BHT isomer has not.

\subsection{BHP distributions in anammox cultures}

\subsubsection{BHT and BHT isomer in anammox cultures}

To determine whether anammox bacteria are responsible for BHT isomer production, the hopanoid composition of three anammox enrichment cultures was investigated (Fig. 4). Several species of anammox bacteria exist, but so far only species belonging to the genus 'Candidatus Scalindua' have been observed in marine systems (Hamersley et al., 2007; Schmid et al., 2007; Pitcher et al., 2011; Borin et al., 2013).

BHT isomer was abundant in the two marine Scalindua enrichment cultures (Fig. $4 \mathrm{a}$ and $4 \mathrm{~b}$ ). A small shoulder detected in the ' $\mathrm{Ca}$. Kuenenia stuttgartiensis' enrichment (Fig. 4c) could be attributed to BHT isomer, but would only make up $1 \%$ of total BHPs in this sample. If BHT isomer is not synthesised in substantial amounts by nonmarine anammox, this may explain the lack of BHT isomer in terrestrial samples. Nevertheless, in order to convincingly conclude that BHT isomer is solely a marine anammox lipid, other non-marine anammox cultures must be screened for their BHP lipid composition.

BHT was observed alongside BHT isomer in the marine anammox cultures (Fig. $4 \mathrm{a}$ and $4 \mathrm{~b}$ ). The proportion of BHT isomer increased in the warmer culture (BHT isomer/(BHT + BHT isomer) was 0.55 at $15^{\circ} \mathrm{C}$ and 0.64 at $\left.23^{\circ} \mathrm{C}\right)$, potentially indicating a temperature dependence. Remarkably, BHT isomer was synthesised in higher relative abundance than BHT, and was the most abundant BHP in both Scalindua enrichments (Fig. 4a and 4b). As far as we know, this is the first observation of BHT isomer in higher relative abundance than BHT in a bacterial culture. However, BHT isomer has been observed in higher relative abundances than 
BHT in three marine sediment samples from the Peru Margin (Watson, 2002), where anammox is known to be an important process (Hamersley et al., 2007; Rush et al., 2012b). These findings strongly support the hypothesis that BHT isomer observed in Golfo Dulce marine samples and other anoxic environments is sourced from anammox bacteria.

This is not, however, the first report of BHT isomer occurring in a bacterial culture. Previously, BHT isomers were identified by NMR in two strains of acetic acid bacteria (Peiseler and Rohmer, 1992). BHT isomer was also tentatively identified (by mass spectral analysis and by comparing chromatographic retention times) in Methylocella palustris, isolated from Sphagnum moss (van Winden et al., 2012). The $22 R, 32 R, 33 R, 34 R$ BHT configuration was found in equal proportion to the $22 R$, $32 R$, 33R, 34S configuration in Frankia sp. (Rosa-Putra et al., 2001) by comparing ${ }^{1} \mathrm{H}$ - and ${ }^{13} \mathrm{C}-\mathrm{NMR}$ spectra to those of hemisynthesised BHT diastereoisomers published in Bisseret and Rohmer (1989). However, the BHT isomer in the first two cultures was only present in low abundance. Although BHTs are the most abundant hopanoid in Frankia (Nalin et al., 2000), other novel Frankia BHPs (e.g. BHTs with C35-substituted propionyl and pheylacetyl groups) described in Rosa-Putra et al. (2001) have, to the best of our knowledge, never been detected in the natural environment. Additionally, none of the aforementioned occurrences of BHT isomer was in a marine bacterium. To our knowledge, the marine anammox bacteria enrichment cultures in this study are the first bacteria in which BHT isomer is the primary BHP in a marine species.

\subsubsection{Novel BHPs in anammox cultures}

The marine anammox enrichments also contained two earlier-eluting composite BHPs, with parent ions of $\mathrm{m} / \mathrm{z} 880$ and $\mathrm{m} / \mathrm{z}$ 894, associated with the indicative protonated base peak ion for BHT ( $\mathrm{m} / \mathrm{z}, 655$; Fig 4 a and b, Fig. 5). We can only speculate that polarity is the reason why these composite-BHPs elute much earlier in the chromatogram than other composite tetrafunctionalised BHPs. We also cannot explain why $m / z 894$ was only found in the ' $C a$. Scalindua profunda' culture grown at $15^{\circ} \mathrm{C}$. However, as these BHPs were both synthesised in low abundances in culture, and as neither was detected in Golfo Dulce sediments, they might not be important in the environment. 
In Sinninghe Damsté et al. (2004) other species of planctomycetes were analysed for hopanoids. Notably, a ubiquitous marine non-anammox planctomycete species, Pirellula marina (Lindsay et al., 1997), was also shown to contain BHT. As the presence of BHT was only confirmed by co-elution with an authentic BHT standard in one sample (' $\mathrm{Ca}$. Brocadia anammoxidans'), it remains a possibility that BHT identified in subsequent GC analyses, including the $P$. marina sample, was in fact $\mathrm{BHT}$ isomer or that the two isomers were not separated on the GC column used for this study. Until the exact BHT stereochemistry can be confirmed in other planctomycetes, caution should be used before interpreting BHT isomer in marine settings as a definitive indicator of pelagic anammox.

\subsection{Environmental occurrences of BHT isomer, and its potential relationship} with anammox bacteria

Despite the few occurrences of BHT isomer in soil bacteria cultures and enrichments (e.g. Peiseler and Rohmer, 1992, Rosa-Putra et al., 2001; van Winden et al., 2012), BHT isomer remains a rarely detected BHP in soil environments. This is likely because these bacteria are specific to particular environmental conditions and/or because they are not important producers of BHPs in the environment. To the best of our knowledge BHT isomer has only ever been detected once in a terrestrial soil environment. Pearson et al. (2009) investigated the distribution of hopanoids across a land-to-sea gradient. BHT isomer was detected in relatively low abundance $(<10 \%$ of BHT) in a tropical soil, where squalene-hopene cyclase genes affiliated with anammox were also found. Although BHT isomer was detected in a nearby creek, where it made up $<2 \%$ of BHT, it was not detected in the shallow open ocean. Talbot et al. (2003c) reported BHT isomer in non-marine sediments, from temperate, high altitude, and saline lakes. However, anammox bacteria cannot be disregarded as the source of BHT isomer in these systems. Anammox activity has been reported previously in several non-marine environments. $16 \mathrm{~S}$ gene sequences affiliated with ' $C a$. Scalindua' spp. were observed in Lake Tanganyika (Schubert et al., 2006), in lake and wetland sediments in Michigan, U.S.A., and subtropical wetland sediments in Florida, U.S.A. (Penton et al., 2006). Anammox species relating to ' $\mathrm{Ca}$. Jettenia asiatica' and ' $\mathrm{Ca}$. Brocadia fulgida' were found in peat soils (Hu et al., 2011), and species relating to ' $\mathrm{Ca}$. Anammoxoglobus' and ' $\mathrm{Ca}$. Jettenia' were found in a flooded rice paddy soil (Hu et al., 2013). $16 \mathrm{~S}$ gene sequences related to ' $\mathrm{Ca}$. Brocadia' were 
found in lake riparian zones in China (Zhu et al., 2013), and genes affiliated with ' $\mathrm{Ca}$. Kuenenia', ' $C a$. Jettenia', and ' $C a$. Scalindua' were found in sediments from two Chinese rivers (Zhao et al., 2013). Clearly, there is need for further investigation of BHP distributions in other anammox genera in order to be able to potentially link anammox as the source of BHT isomer in non-marine settings.

A re-examination of previous marine BHT isomer occurrences supports its association with anammox bacteria in marine environments other than Golfo Dulce. The co-occurrence of anammox ladderane fatty acids and BHT isomer in Golfo Dulce sediments are comparable to water column data from the Cariaco Basin, an anoxic basin off the coast of Venezuela (Wakeham et al., 2012). The peak in BHT isomer concentration in Cariaco Basin occurred within the core chemocline, where oxygen concentrations were below detection limit. The peak in ladderane fatty acids in the Cariaco Basin corresponded with this peak in the BHT isomer. Furthermore, anammox bacterial cell counts, using FISH, were highest within the chemocline. Both BHT isomer and ladderane lipids were not detected in the deeper, anoxic and sulfidic water column.

Further circumstantial evidence that marine anammox bacteria are synthesising BHT isomer comes from the sites studied by Sáenz et al. (2011). The environments where BHT isomer was detected were all marine settings in which active anammox communities have been described previously, i.e., in the Arabian Sea (Pitcher et al., 2011), and the Peru Margin (Hamersley et al., 2007). As mentioned previously, BHT isomer was also reported in sediments from the Benguela Upwelling system (Blumenberg et al., 2010), where Kuypers et al. (2005) used nitrogen isotope labelling, phylogenetic, and lipid analyses to demonstrate that anammox was an important process in the overlying waters. Similarly, a recent study of BHPs in Gotland Deep, central Baltic Sea (Berndmeyer et al., 2013) revealed BHT isomer to be present in a well-developed "suboxic zone" of the water column (108 - $135 \mathrm{~m}$ water depth) as well as in surface sediments $(0-8 \mathrm{cmbsf})$. Anammox activity was previously detected in the suboxic and anoxic water of Gotland Deep following a complete ventilation of the basin (Hannig et al., 2007). Kharbush et al. (2013) detected BHT isomer in the anoxic part of the California Current water column, in which anammox squalene-hopene cyclase gene sequences were also amplified. Combined, these studies indicate that anammox production of BHT isomer may be a widespread marine water column process. 


\subsection{Implications for the marine sedimentary record}

We show here, for the first time, that enrichment cultures dominated by marine anammox bacteria synthesise BHT isomer in high abundance. Therefore, it is likely that the presence of BHT isomer in marine sediment is due to anammox activity. Thus far, the oldest known occurrence of BHPs is in 54.4 Ma sediments from Kilwa, Tanzania (van Dongen et al., 2006), and BHT isomer has been observed in 1.75 Ma marine sediments from the Benguela upwelling region (Watson, 2002). In contrast, the oldest fossil occurrence of ladderane fatty acids was in 140 ka Arabian Sea sediments (Jaeschke et al., 2009). A preferential degradation of ladderane fatty acids can already be observed in the scatter plot of BHT isomer versus ladderanes in the deeper Golfo Dulce cores (Fig. 6b; dashed line). The slope of the line of best fit is much steeper for the deeper sediments than that for the surface sediments (Fig. 6a) and shallow core sediments (Fig. 6b; dotted line), indicating a relative decrease in ladderane fatty acid concentrations. As BHPs are evidentially better preserved than ladderanes in sediment, BHT isomer may likely be a more appropriate biomarker for identifying anammox in the geological past.

\section{CONCLUSIONS}

Ladderane fatty acid and bacteriohopanepolyol distributions in Golfo Dulce sediments strongly suggest that anammox bacteria were responsible for the presence of the BHT isomer is this environmental setting. This hypothesis is supported by the confirmed presence of BHT isomer in two 'Candidatus Scalindua profunda' anammox enrichments. BHT isomer was not detected in a non-marine anammox enrichment (dominated by species 'Candidatus Kuenenia stuttgartiensis'). These results indicate that marine anammox are likely responsible for at least some of the marine BHT isomer occurrences thus far observed, and that BHT isomer might be a stable, more suitable biomarker than ladderane fatty acids for past anammox activity.

The exact stereochemistry of the BHT isomer remains unknown, requiring 2DNMR studies to fully elucidate its structure. However, as marine anammox bacteria are difficult to culture, obtaining enough cell material to isolate BHT isomer with preparative LC was not possible in this study, but should be considered in future work. 
As with any novel potential biomarker, many questions remain. Why do only certain species of (marine) anammox bacteria synthesise BHT isomer? How does temperature regulate BHT isomer distributions? What is the role of the other composite-BHTs found in the cultures? However, such fundamental questions relate not only to BHT isomer, but to BHPs in general, emphasising the importance of further studies on BHP regulation and membrane physiology.

Marine sediments in settings where anammox is known to be an important process (i.e. oxygen minimum zones, anoxic basins) should be screened for the presence of BHT isomer in order to validate its use as a biomarker for paleoanammox activity. Optimistically, these studies will reveal the merit of using BHT isomer as a biomarker for past anammox activity, and advocate the use of BHT isomer in demonstrating past changes in the relative importance of anammox (as seen in the Baltic Sea), as well as fluctuations in nitrogen cycling in response to ocean redox changes through the geological record.

\section{ACKNOWLEDGEMENTS}

We kindly thank Marianne Baas (NIOZ) for assistance with ASE extraction, and Ellen Hopmans (NIOZ) for HPLC-APCI-MS/MS discussions. We thank the Science Research Infrastructure Fund (SRIF) from the HEFCE for funding the purchase of a ThermoFinnigan LCQ ion trap mass spectrometer (Newcastle University). Frances Sidgwick (Newcastle University) is thanked for assistance with the HPLC-APCI-MS work. Further thanks go to Wiebe Abma (Paques BV) for supplying the waste water anammox cell material. We thank CIMAR for facilitating the joint project. This project was partially funded by the Darwin Centre for Biogeosciences (publication number DW-2014-1004) by a grant to JSSD. The work was also partially funded by a Starting Grant (No. 258734) awarded to HMT for project AMOPROX, and an Advanced Grant (No. 232937) awarded to MSMJ for project ANAMMOX, both from the European Research Council, to whom we are extremely grateful. This manuscript was improved thanks to comments by Roger Summons and two other reviews. 


\section{REFERENCES}

Berndmeyer, C., Thiel, V., Schmale, O. and Blumenberg, M. (2013) Biomarkers for aerobic methanotrophy in the water column of the stratified Gotland Deep (Baltic Sea). Org. Geochem. 55, 103-111.

Bisseret, P. and Rohmer, M. (1989) Bacterial sterol surrogates - determination of the absolute-configuration of bacteriohopanetetrol side-chain by hemisynthesis of its diastereoisomers. J. Org. Chem.54, 2958-2964.

Bligh, E. G. and Dyer, W. J. (1959) A rapid method of total lipid extraction and purification. Can. J. Biochem. Physiol. 37, 911-917.

Blumenberg, M., Kruger, M., Nauhaus, K., Talbot, H. M., Oppermann, B. I., Seifert, R., Pape, T. and Michaelis, W. (2006) Biosynthesis of hopanoids by sulfatereducing bacteria (genus Desulfovibrio). Environ. Microbiol. 8, 1220-1227.

Blumenberg, M., Mollenhauer, G., Zabel, M., Reimer, A. and Thiel, V. (2010) Decoupling of bio- and geohopanoids in sediments of the Benguela Upwelling System (BUS). Org. Geochem. 41, 1119-1129.

Borin, S., Mapelli, F., Rolli, E., Song, B., Tobias, C., Schmid, M. C., De Lange, G. J., Reichart, G. J., Schouten, S., Jetten, M. and Daffonchio, D. (2013) Anammox bacterial populations in deep marine hypersaline gradient systems. Extremophiles 17, 289-299.

Boumann, H. A., Hopmans, E. C., van de Leemput, I., Op den Camp, H. J. M., van de Vossenberg, J., Strous, M., Jetten, M. S. M., Sinninghe Damsté, J. S. and Schouten, S. (2006) Ladderane phospholipids in anammox bacteria comprise phosphocholine and phosphoethanolamine headgroups. FEMS Microbiol. Lett. 258, 297-304.

Brocks, J. J. and Pearson, A. (2005) Building the biomarker tree of life. In Molecular Geomicrobiology (eds J. E. Banfield, J. Cervini Silva, and K. H. Nealson)

Canfield, D. E. and Thamdrup, B. (2009) Towards a consistent classification scheme for geochemical environments, or, why we wish the term 'suboxic' would go away. Geobiology 7, 385-392.

Cooke, M. P., Talbot, H. M. and Farrimond, P. (2008) Bacterial populations recorded in bacteriohopanepolyol distributions in soils from Northern England. Org. Geochem. 39, 1347-1358.

Cooke, M. P. (2010) The role of bacteriohopanepolyols as biomarkers for soil bacterial communities and soil derived organic matter, Ph.D thesis, Newcastle University, UK.

Cvejic, J. H., Bodrossy, L., Kovacs, K. L. and Rohmer, M. (2000) Bacterial triterpenoids of the hopane series from the methanotrophic bacteria Methylocaldum spp.: phylogenetic implications and first evidence for an unsaturated aminobacteriopanepolyol. FEMS Microbiol. Lett. 182, 361-365.

Dalsgaard, T., Canfield, D. E., Petersen, J., Thamdrup, B. and Acuna-Gonzalez, J. (2003) $\mathrm{N}_{2}$ production by the anammox reaction in the anoxic water column of Golfo Dulce, Costa Rica. Nature 422, 606-608.

Doughty, D. M., Hunter, R. C., Summons, R. E. and Newman, D. K. (2009) 2Methylhopanoids are maximally produced in akinetes of Nostoc punctiforme: geobiological implications. Geobiology 7, 524-532. 
Eickhoff, M., Birgel, D., Talbot, H. M., Peckmann, J. and Kappler, A. (2013) Bacteriohopanoid inventory of Geobacter sulfurreducens and Geobacter metallireducens. Org. Geochem. 58, 107-114.

Farrimond, P., Fox, P. A., Innes, H. E., Miskin, I. P. and Head, I. M. (1998) Bacterial sources of hopanoids in recent sediments: improving our understanding of ancient hopane biomarkers. Anc. Biomol. 2, 147-166.

Ferdelman, T. G., Thamdrup, B., Canfield, D. E., Glud, R. N., Kuever, J., Lillebaek, R., Ramsing, N. B. and Wawer, C. (2006) Biogeochemical controls on the oxygen, nitrogen and sulfur distributions in the water column of Golfo Dulce: an anoxic basin on the Pacific coast of Costa Rica revisited. Rev.Biol. Trop. 54, 171-191.

Fischer, W. W., Summons, R. E. and Pearson, A. (2005) Targeted genomic detection of biosynthetic pathways: anaerobic production of hopanoid biomarkers by a common sedimentary microbe. Geobiology 3, 33-40.

Grasshoff, K. (1983). Determination of oxygen. In Methods of Seawater Analysis (eds K. Grasshoff, M. Ehrhardt, and K. Kremling), Verlag Chemie, Weinheim.

Hamersley, M. R., Lavik, G., Woebken, D., Rattray, J. E., Lam, P., Hopmans, E. C., Sinninghe Damsté, J. S., Kruger, S., Graco, M., Gutierrez, D. and Kuypers, M. M. M. (2007) Anaerobic ammonium oxidation in the Peruvian oxygen minimum zone. Limnol. Oceanogr. 52, 923-933.

Hannig, M., Lavik, G., Kuypers, M. M. M., Woebken, D., Martens-Habbena, W. and Jurgens, K. (2007) Shift from denitrification to anammox after inflow events in the central Baltic Sea. Limnol.Oceanogr. 52, 1336-1345.

Hebbeln, D., Beese, D. and Cortes, J. (1996) Morphology and sediment structures in Golfo Dulce, Costa Rica. Rev.Biol. Trop. 44, 1-10.

Hopmans, E. C., Kienhuis, M. V. M., Rattray, J. E., Jaeschke, A., Schouten, S. and Sinninghe Damsté, J. S. (2006) Improved analysis of ladderane lipids in biomass and sediments using high-performance liquid chromatography/atmospheric pressure chemical ionization tandem mass spectrometry. Rapid Commun. Mass Spectrom. 20, 2099-2103.

Hu, B.-I., Rush, D., van der Biezen, E., Zheng, P., van Mullekom, M., Schouten, S., Damste, J. S. S., Smolders, A. J. P., Jetten, M. S. M. and Kartal, B. (2011) New Anaerobic, Ammonium-Oxidizing Community Enriched from Peat Soil. Appl. Environ. Microbiol. 77, 966-971.

Hu, B.-I., Shen, L.-D., Liu, S., Cai, C., Chen, T.-T., Kartal, B., Harhangi, H. R., Op den Camp, H. J. M., Lou, L.-P., Xu, X.-Y., Zheng, P. and Jetten, M. S. M. (2013) Enrichment of an anammox bacterial community from a flooded paddy soil. Environ. Microbiol. Rep. 5, 483-489.

Jaeschke, A., Lewan, M. D., Hopmans, E. C., Schouten, S. and Sinninghe Damsté, J. S. (2008) Thermal stability of ladderane lipids as determined by hydrous pyrolysis. Org. Geochem. 39, 1735-1741.

Jaeschke, A., Ziegler, M., Hopmans, E. C., Reichart, G. J., Lourens, L. J., Schouten, S. and Sinninghe Damsté, J. S. (2009) Molecular fossil evidence for anaerobic ammonium oxidation in the Arabian Sea over the last glacial cycle. Paleoceanography 24.

Kannenberg, E. L. and Poralla, K. (1999) Hopanoid biosynthesis and function in bacteria. Naturwissenschaften 86, 168-176. 
Kharbush, J. J., Ugalde, J. A., Hogle, S. L., Allen, E. E. and Aluwihare, L. I. (2013) Composite bacterial hopanoids and their microbial producers across oxygen gradients in the water column of the California Current. Appl. Environ. Microb. 79, 7491-7501.

Kuypers, M. M. M., Sliekers, A. O., Lavik, G., Schmid, M., Jorgensen, B. B., Kuenen, J. G., Sinninghe Damsté, J. S., Strous, M. and Jetten, M. S. M. (2003) Anaerobic ammonium oxidation by anammox bacteria in the Black Sea. Nature 422, 608-611.

Kuypers, M. M. M., van Breugel, Y., Schouten, S., Erba, E. and Sinninghe Damsté, J. S. (2004) N-2-fixing cyanobacteria supplied nutrient N for Cretaceous oceanic anoxic events. Geology 32, 853-856.

Kuypers, M. M. M., Lavik, G., Woebken, D., Schmid, M., Fuchs, B. M., Amann, R., Jørgensen, B. B. and Jetten, M. S. M. (2005) Massive nitrogen loss from the Benguela upwelling system through anaerobic ammonium oxidation. PNAS 102, 6478-6483.

Lindsay, M. R., Webb, R. I. and Fuerst, J. A. (1997) Pirellulosomes: A new type of membrane-bounded cell compartment in planctomycete bacteria of the genus Pirellula. Microbiol.-UK 143, 739-748.

Nalin, R., Rosa-Putra, S., Domenach, A. M., Rohmer, M., Gourbière, F. and Berry, A. M. (2000) High hopanoid/total lipids ratio in Frankia mycelia is not related to the nitrogen status. Microbiology 146, 3013-3019.

Ourisson, G., Rohmer, M. and Poralla, K. (1987) Prokaryotic hopanoids and other polyterpenoid sterol surrogates. Annu. Rev. Microbiol. 41, 301-333.

Ourisson, G. and Albrecht, P. (1992) Hopanoids 1. Geohopanoids - the most abundant natural-products on earth. Accounts Chem. Res. 25, 398-402.

Pearson, A., Page, S. R. F., Jorgenson, T. L., Fischer, W. W. and Higgins, M. B. (2007) Novel hopanoid cyclases from the environment. Environ. Microbiol. 9, 2175-2188.

Pearson, A., Leavitt, W. D., Sáenz, J. P., Summons, R. E., Tam, M. C. M. and Close, H. G. (2009) Diversity of hopanoids and squalene-hopene cyclases across a tropical land-sea gradient. Environ. Microbiol. 11, 1208-1223.

Peiseler, B. and Rohmer, M., 1992. Prokaryotic triterpenoids of the hopane series Bacteriohopanetetrols of new side-chain configuration from Acetobacter species. J. Chem. Res.-S, 298-299.

Penton, C. R., Devol, A. H. and Tiedje, J. M. (2006) Molecular evidence for the broad distribution of anaerobic ammonium-oxidizing bacteria in freshwater and marine sediments. Appl. Environ. Microbiol. 72, 6829-6832.

Pitcher, A., Villanueva, L., Hopmans, E. C., Schouten, S., Reichart, G. J. and Sinninghe Damsté, J. S. (2011) Niche segregation of ammonia-oxidizing archaea and anammox bacteria in the Arabian Sea oxygen minimum zone. ISME Journal 5, 1896-1904.

Rattray, J. E., van de Vossenberg, J., Hopmans, E. C., Kartal, B., van Niftrik, L., Rijpstra, W. I. C., Strous, M., Jetten, M. S. M., Schouten, S. and Sinninghe Damsté, J. S. (2008) Ladderane lipid distribution in four genera of anammox bacteria. Arch. Microbiol. 190, 51-66.

Rattray, J. E., van de Vossenberg, J., Jaeschke, A., Hopmans, E. C., Wakeham, S. G., Lavik, G., Kuypers, M. M. M., Strous, M., Jetten, M. S. M., Schouten, S. and Sinninghe Damsté, J. S. (2010) Impact of Temperature on Ladderane 
Lipid Distribution in Anammox Bacteria. Appl. Environ. Microbiol. 76, 15961603.

Richards, F. A., Anderson, J. J. and Cline, J. D. (1971) Chemical and physical observations in Golfo Dulce, an anoxic basin on pacific coast of Costa-Rica. Limnol.Oceanogr. 16, 43-50.

Rohmer, M., Bouviernave, P. and Ourisson, G. (1984) Distribution of Hopanoid Triterpenes in Prokaryotes. J. Gen. Microbiol. 130, 1137-1150.

Rosa-Putra, S., Nalin, R., Domenach, A.-M., and Rohmer, M. (2001) Novel hopanoids from Frankia spp. and related soil bacteria - Squalene cyclization and significance of geological biomarkers revisited. Eur. J. Biochem. 268, 4300-4306.

Rush, D., Jaeschke, A., Hopmans, E. C., Geenevasen, J. A. J., Schouten, S. and Sinninghe Damsté, J. S. (2011) Short chain ladderanes: Oxic biodegradation products of anammox lipids. Geochim. Cosmochim. Acta 75, 1662-1671.

Rush, D., Wakeham, S. G., Hopmans, E. C., Schouten, S. and Sinninghe Damsté, J. S. (2012a) Biomarker evidence for anammox in the oxygen minimum zone of the Eastern Tropical North Pacific. Org. Geochem. 53, 80-87.

Rush, D., Hopmans, E. C., Wakeham, S. G., Schouten, S. and Sinninghe Damsté, J. $\mathrm{S}$. (2012b) Occurrence and distribution of ladderane oxidation products in different oceanic regimes. Biogeosciences 9, 2407-2418.

Sáenz, J. P., Wakeham, S. G., Eglinton, T. I. and Summons, R. E. (2011) New constraints on the provenance of hopanoids in the marine geologic record: Bacteriohopanepolyols in marine suboxic and anoxic environments. Org. Geochem. 42, 1351-1362.

Sáenz, J. P., Sezgin, E., Schwille, P. and Simons, K. (2012) Functional convergence of hopanoids and sterols in membrane ordering. PNAS 109, 14236-14240.

Schmid, M., Twachtmann, U., Klein, M., Strous, M., Juretschko, S., Jetten, M., Metzger, J. W., Schleifer, K. H. and Wagner, M. (2000) Molecular evidence for genus level diversity of bacteria capable of catalyzing anaerobic ammonium oxidation. Syst. Appl. Microbiol. 23, 93-106.

Schmid, M. C., Risgaard-Petersen, N., van de Vossenberg, J., Kuypers, M. M. M., Lavik, G., Petersen, J., Hulth, S., Thamdrup, B., Canfield, D., Dalsgaard, T., Rysgaard, S., Sejr, M. K., Strous, M., den Camp, H. and Jetten, M. S. M. (2007) Anaerobic ammonium-oxidizing bacteria in marine environments: widespread occurrence but low diversity. Environ. Microbiol. 9, 1476-1484.

Schubert C. J., Durisch-Kaiser E., Wehrli B., Thamdrup B., Lam P. and Kuypers M. M. M. (2006) Anaerobic ammonium oxidation in a tropical freshwater system (Lake Tanganyika). Environ. Microbiol. 8, 1857-1863.

Sinninghe Damsté, J. S., Strous, M., Rijpstra, W. I. C., Hopmans, E. C., Geenevasen, J. A. J., van Duin, A. C. T., van Niftrik, L. A. and Jetten, M. S. M. (2002) Linearly concatenated cyclobutane lipids form a dense bacterial membrane. Nature 419.

Sinninghe Damsté, J. S., Rijpstra, W. I. C., Schouten, S., Fuerst, J. A., Jetten, M. S. M. and Strous, M. (2004). The occurrence of hopanoids in planctomycetes: implications for the sedimentary biomarker record. Org. Geochem. 35, 561566.

Strous, M., Pelletier, E., Mangenot, S., Rattei, T., Lehner, A., Taylor, M. W., Horn, M., Daims, H., Bartol-Mavel, D., Wincker, P., Barbe, V., Fonknechten, N., 
Vallenet, D., Segurens, B., Schenowitz-Truong, C., Medigue, C., Collingro, A., Snel, B., Dutilh, B. E., Op den Camp, H. J. M., van der Drift, C., Cirpus, I., van de Pas-Schoonen, K. T., Harhangi, H. R., van Niftrik, L., Schmid, M., Keltjens, J., van de Vossenberg, J., Kartal, B., Meier, H., Frishman, D., Huynen, M. A., Mewes, H. W., Weissenbach, J., Jetten, M. S. M., Wagner, M. and Le Paslier, D. (2006) Deciphering the evolution and metabolism of an anammox bacterium from a community genome. Nature 440, 790-794.

Summons, R. E., Jahnke, L. L., Hope, J. M. and Logan, G. A. (1999) 2Methylhopanoids as biomarkers for cyanobacterial oxygenic photosynthesis. Nature 400, 554-557.

Talbot, H. M., Squier, A. H., Keely, B. J. and Farrimond, P. (2003a) Atmospheric pressure chemical ionisation reversed-phase liquid chromatography/ion trap mass spectrometry of intact bacteriohopanepolyols. Rapid Commun. Mass Spectrom. 17, 728-737.

Talbot, H. M., Summons, R., Jahnke, L. and Farrimond, P. (2003b) Characteristic fragmentation of bacteriohopanepolyols during atmospheric pressure chemical ionisation liquid chromatography/ion trap mass spectrometry. Rapid Commun. Mass Spectrom. 17, 2788-2796.

Talbot, H. M., Watson, D. F., Pearson, E. J. and Farrimond, P. (2003c) Diverse biohopanoid compositions of non-marine sediments. Org. Geochem. 34, 1353-1371.

Talbot, H. M., Rohmer, M. and Farrimond, P. (2007) Rapid structural elucidation of composite bacterial hopanoids by atmospheric pressure chemical ionisation liquid chromatography/ion trap mass spectrometry. Rapid Commun. Mass Spectrom. 21, 880-892.

Talbot, H. M., Coolen, M. J. L. and Sinninghe Damsté, J. S. (2008a) An unusual $17 \alpha, 21 \beta(H)$-bacteriohopanetetrol in Holocene sediments from Ace Lake (Antarctica). Org. Geochem. 39, 1029-1032.

Talbot, H. M., Summons, R. E., Jahnke, L. L., Cockell, C. S., Rohmer, M. and Farrimond, P. (2008b) Cyanobacterial bacteriohopanepolyol signatures from cultures and natural environmental settings. Org. Geochem. 39, 232-263.

Thamdrup, B., Canfield, D. E., Ferdelman, T. G., Glud, R. N. and Gundersen, J. K. (1996) A biogeochemical survey of the anoxic basin Golfo Dulce, Costa Rica. Rev. Biol. Trop. 44, 19-33.

Thamdrup, B. and Dalsgaard, T. (2002) Production of N-2 through anaerobic ammonium oxidation coupled to nitrate reduction in marine sediments. Appl. Environ. Microbiol. 68, 1312-1318.

van de Vossenberg, J., Rattray, J. E., Geerts, W., Kartal, B., van Niftrik, L., van Donselaar, E. G., Sinninghe Damsté, J. S., Strous, M. and Jetten, M. S. M. (2008) Enrichment and characterization of marine anammox bacteria associated with global nitrogen gas production. Environ. Microbiol. 10, 31203129.

van de Vossenberg, J., Woebken, D., Maalcke, W. J., Wessels, H. J. C. T., Dutilh, B. E., Kartal, B., Janssen-Megens, E. M., Roeselers, G., Yan, J., Speth, D., Gloerich, J., Geerts, W., van der Biezen, E., Pluk, W., Francoijs, K.-J., Russ, L., Lam, P., Malfatti, S. A., Tringe, S. G., Haaijer, S. C. M., Op den Camp, H. J. M., Stunnenberg, H. G., Amann, R., Kuypers, M. M. M. and Jetten, M. S. M. (2013) The metagenome of the marine anammox bacterium 'Candidatus 
Scalindua profunda' illustrates the versatility of this globally important nitrogen cycle bacterium. Environ. Microbiol. 15, 1275-1289.

van Dongen, B. E., Talbot, H. M., Schouten, S., Pearson, P. N. and Pancost, R. D. (2006) Well preserved Palaeogene and Cretaceous biomarkers from the Kilwa area, Tanzania. Org. Geochem. 37, 539-557.

van Winden, J. F., Talbot, H. M., Kip, N., Reichart, G. J., Pol, A., McNamara, N. P., Jetten, M. S. M., den Camp, H. and Sinninghe Damsté, J. S. (2012) Bacteriohopanepolyol signatures as markers for methanotrophic bacteria in peat moss. Geochim. Cosmochim. Acta 77, 52-61.

Wakeham, S. G., Turich, C., Schubotz, F., Podlaska, A., Li, X. N. N., Varela, R., Astor, Y., Sáenz, J. P., Rush, D., Sinninghe Damsté, J. S., Summons, R. E., Scranton, M. I., Taylor, G. T. and Hinrichs, K. U. (2012) Biomarkers, chemistry and microbiology show chemoautotrophy in a multilayer chemocline in the Cariaco Basin. Deep-Sea Res. Pt I 63, 133-156.

Watson, D. F. (2002) Environmental distribution and sedimentary fate of hopanoid biological marker compounds. PhD Thesis, Newcastle University, UK.

Welander, P. V. and Summons, R. E. (2012) Discovery, taxonomic distribution, and phenotypic characterization of a gene required for 3-methylhopanoid production. PNAS 109, 12905-12910.

Zhao, Y., Xia, Y., Kana, T. M., Wu, Y., Li, X. and Yan, X. (2013) Seasonal variation and controlling factors of anaerobic ammonium oxidation in freshwater river sediments in the Taihu Lake region of China. Chemosphere 93, 2124-2131.

Zhu, G., Wang, S., Wang, W., Wang, Y., Zhou, L., Jiang, B., Op den Camp, H. J. M., Risgaard-Petersen, N., Schwark, L., Peng, Y., Hefting, M. M., Jetten, M. S. M. and Yin, C. (2013) Hotspots of anaerobic ammonium oxidation at landfreshwater interfaces. Nat. Geosci. 6, 103-107.

Zundel, M. and Rohmer, M. (1985) Prokaryotic triterpenoids. 1. 3-betamethylhopanoids from Acetobacter species and Methylococcus-capsulatus. Eur. J. Biochem. 150, 23-27. 


\section{FIGURES}
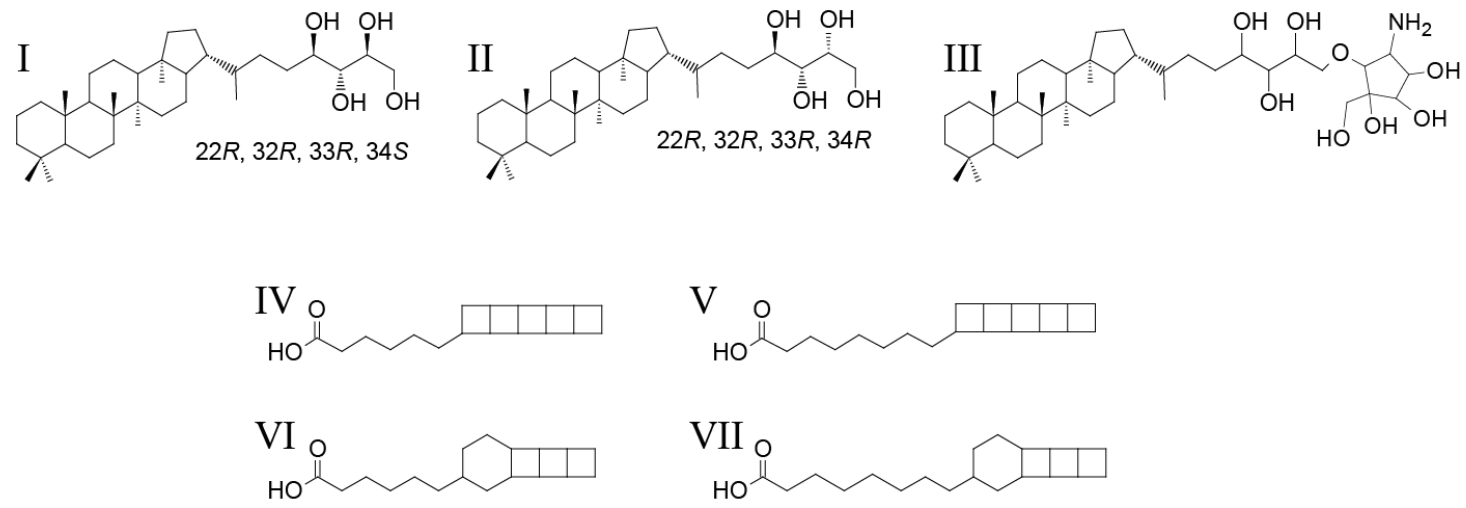

Figure 1. Chemical structures of BHPs and ladderane fatty acids: (I) bacteriohopanetetrol (BHT), (II) bacteriohopanetetrol isomer (BHT isomer); the exact stereoisomer structure is unknown, however, $22 R, 32 R, 33 R, 34 R$ is a likely structure, (III) BHT cyclitol ether, (IV) $\mathrm{C}_{18}$-[5]-ladderane fatty acid, (V) $\mathrm{C}_{20}$-[5]-ladderane fatty acid, (VI) $\mathrm{C}_{18}$-[3]-ladderane fatty acid, and (VII) $\mathrm{C}_{20}$-[3]-ladderane fatty acid. Proposed stereochemistry of BHT isomer (II) from Peiseler and Rohmer (1992).

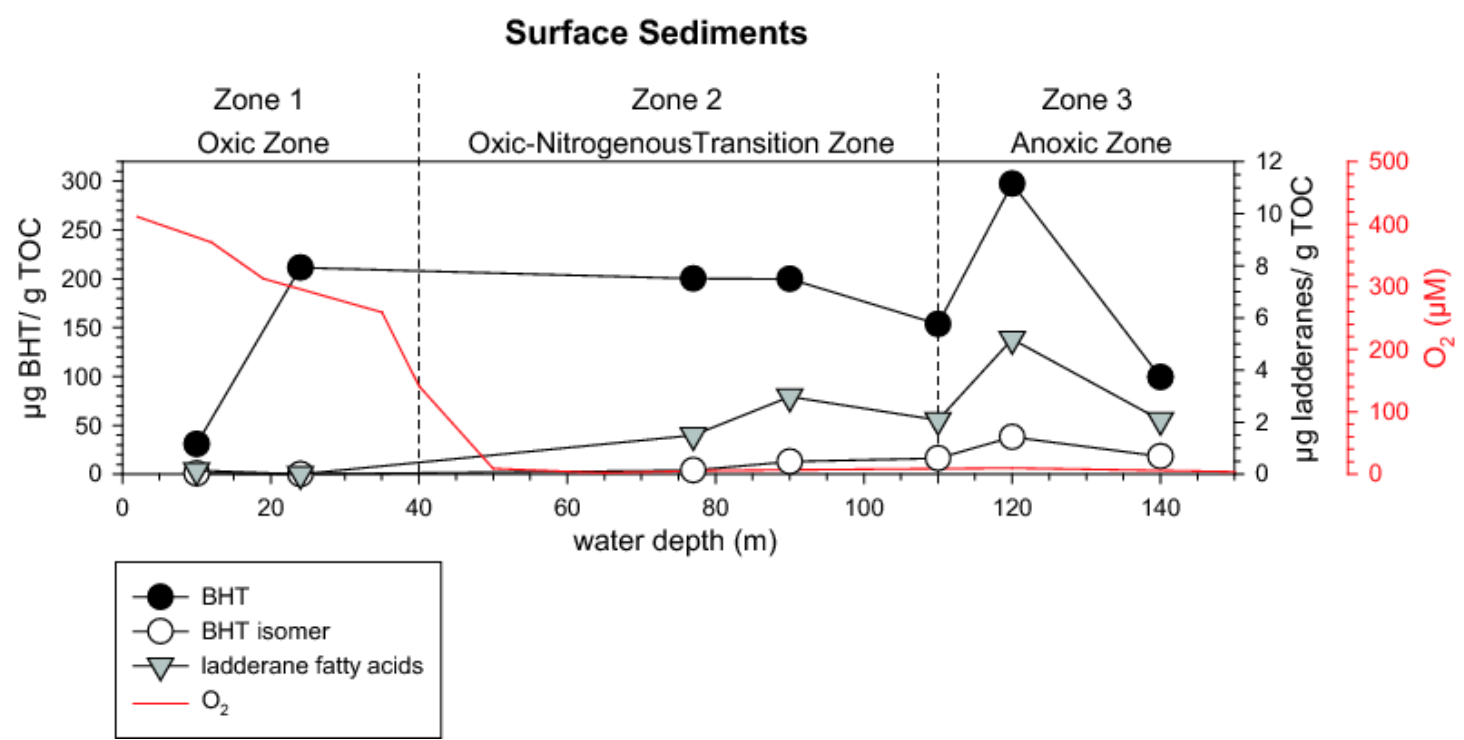

Figure 2: BHT (black circles), BHT isomer (white circles), and ladderane fatty acid (grey triangles) concentrations (expressed in $\mu \mathrm{g} \cdot \mathrm{g}^{-1} \mathrm{TOC}$ ) along a sediment surface transect across the three distinct chemical zones in Golfo Dulce. Analytical reproducibility for BHT and BHT isomer was $\pm 20 \%$. Analytical reproducibility for ladderane fatty acids was $\pm 8 \%$. Oxygen concentration $(\mu \mathrm{M})$ was measured by Winkler titration at water depths of 2, 12, 19, 35, 50, 65, 80, 120 and $170 \mathrm{~m}$, and is shown in red. 


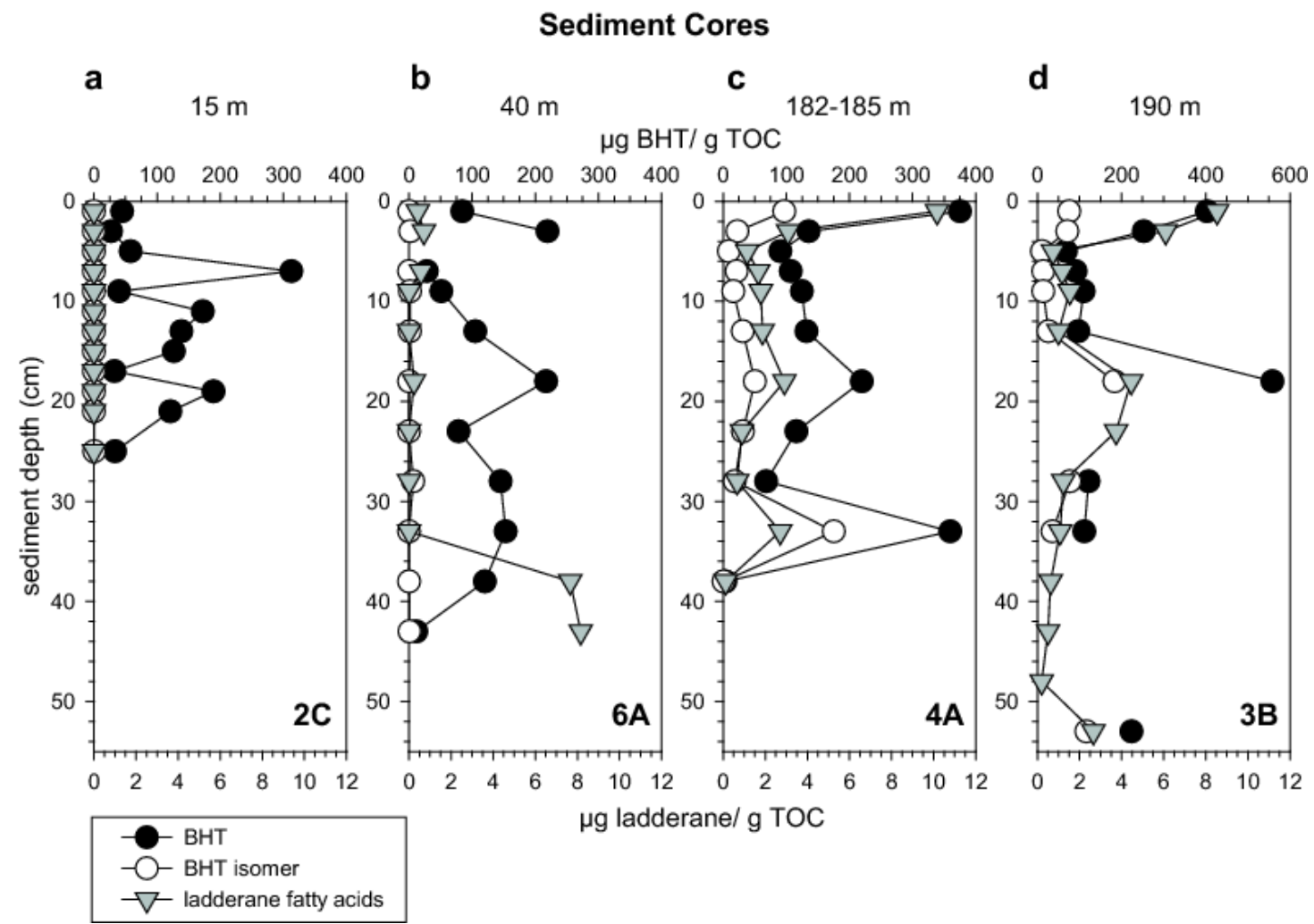

Figure 3: BHT (black circles), BHT isomer (white circles), and ladderane fatty acid (grey triangles) concentrations (expressed in $\mu \mathrm{g} \cdot \mathrm{g}^{-1} \mathrm{TOC}$ ) in Golfo Dulce sediment cores (a) oxic zone (15 m water depth), (b) oxic-nitrogenous transition zone (40 m water depth), (c) anoxic zone (182-185 m water depth), (d) anoxic zone (190 m water depth). Reproducibility for BHT and BHT isomer was $\pm 20 \%$. Reproducibility for ladderane fatty acids was $\pm 8 \%$. Note the scale for BHT concentration is different in (d). Missing BHP data points are due to samples being completely used for ladderane analyses.
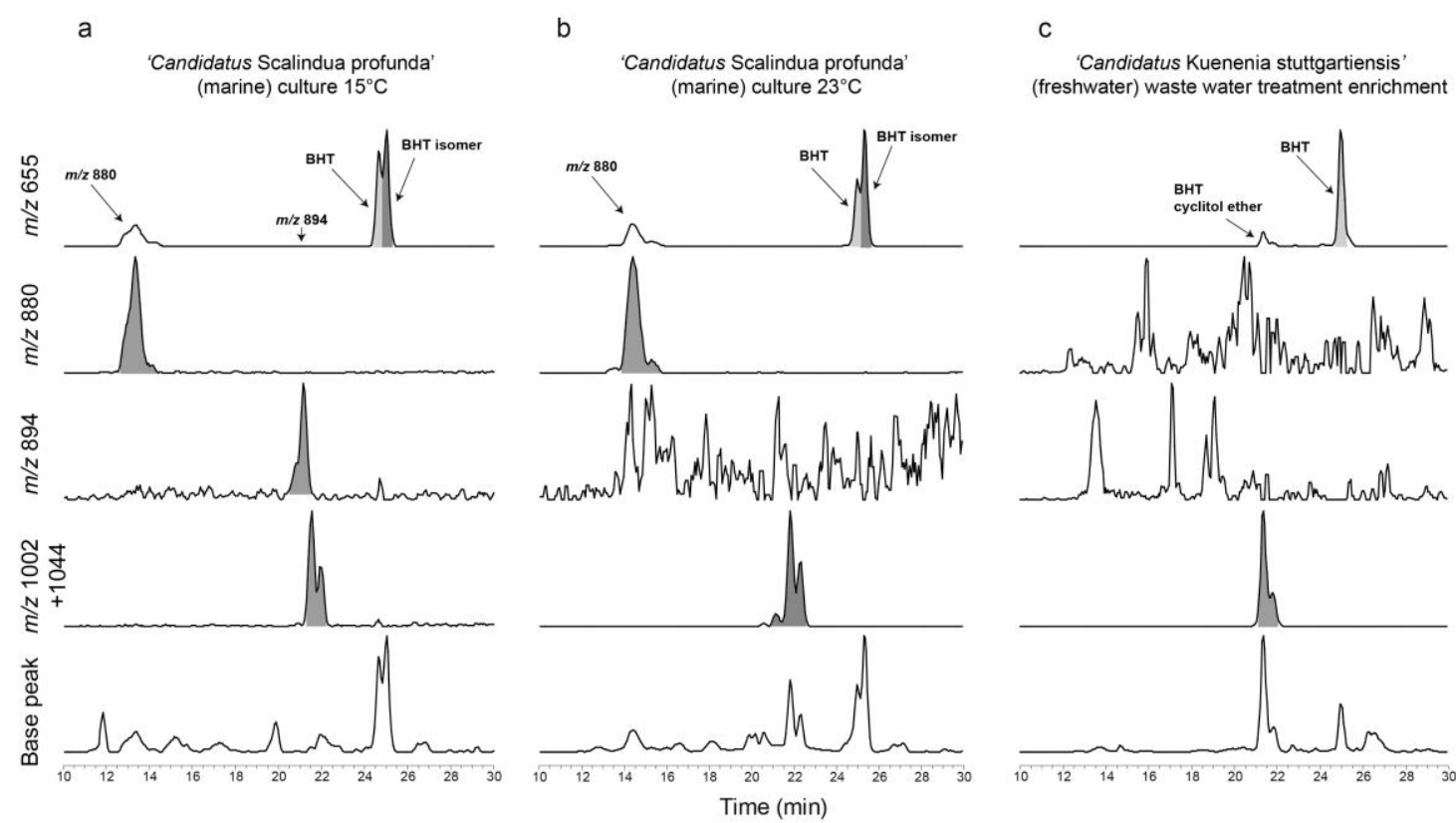
(freshwater) waste water treatment enrichment

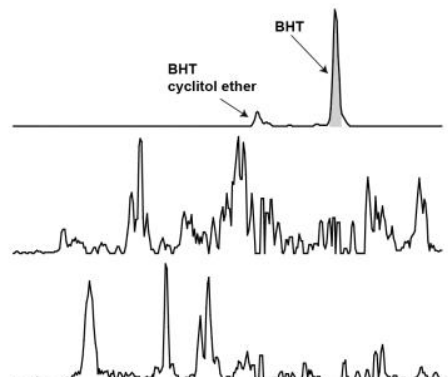

Figure 4. Base peak and mass chromatograms of $\mathrm{m} / z, 655$ (indicative protonated base peak ion for BHT and BHT isomer), $\mathrm{m} / \mathrm{z} 880, \mathrm{~m} / \mathrm{z} 894$, and $\mathrm{m} / \mathrm{z} 1002+1044$ (indicative protonated ions for BHT cyclitol ether) in (a) 'Candidatus Scalindua 
profunda', cultured at $15^{\circ} \mathrm{C}$, (b) 'Candidatus Scalindua profunda', cultured at $23^{\circ} \mathrm{C}$, and (c) 'Candidatus Kuenenia stuttgartiensis', in enriched sludge from a wastewater treatment plant.

a
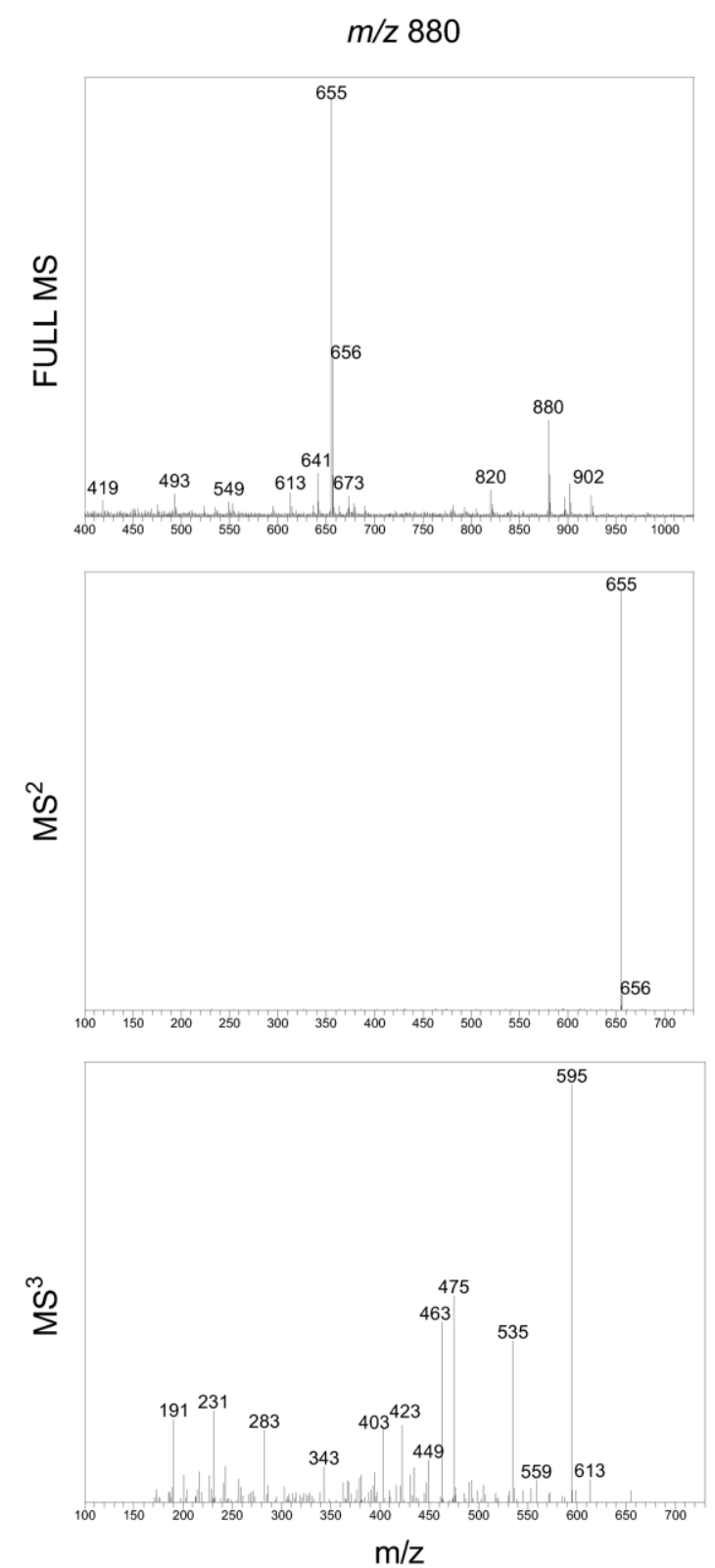

b
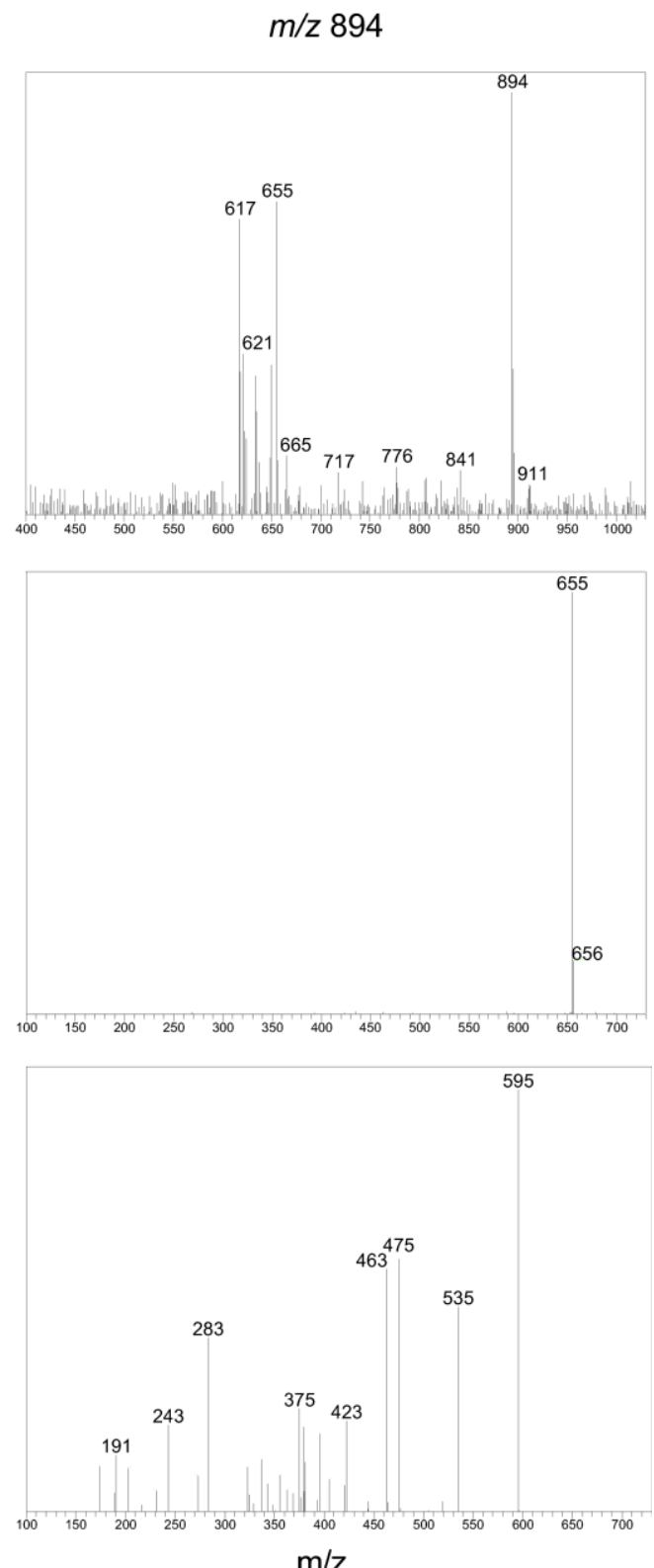

Figure 5. APCI mass spectra of novel BHPs with proposed $[\mathrm{M}+\mathrm{H}]^{+}$of (a) $\mathrm{m} / z .880$ and (b) $m / z 894$ (peaks indicated in Fig. 4) in 'Candidatus Scalindua profunda' cultured at $15{ }^{\circ} \mathrm{C} . \mathrm{MS}^{2}$ and $\mathrm{MS}^{3}$ were obtained from targeted scanning of $\mathrm{m} / \mathrm{z} 655,880$ and 894 of the same sample. Note that full MS were corrected for background. 
a

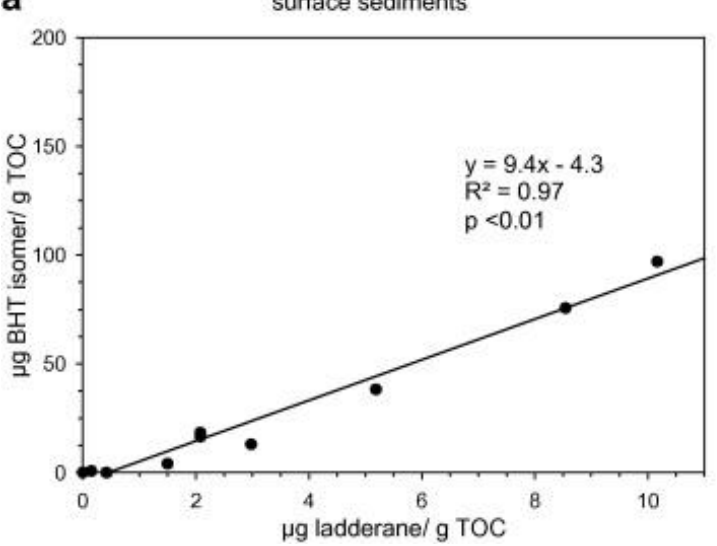

b

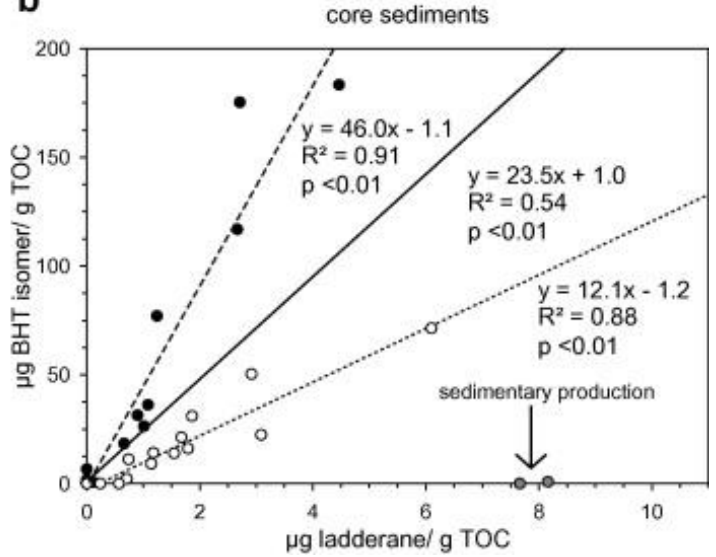

Figure 6: Scatter plot of ladderane fatty acid concentrations versus BHT isomer concentration in Golfo Dulce surface sediments (a) and deeper, core sediments (b). Data points for (a) are from transect samples $(0-0.5 \mathrm{~cm}$; Fig. 2$)$ and core tops $(0-2$ $\mathrm{cm}$; Fig. 3). Dashed line in (b) is line of best fit for sediments (closed circles) possibly affected by preferential degradation of ladderane fatty acids (Core $3 \mathrm{~B},>22 \mathrm{cmbsf}$; Core 4A, >22 cmbsf; Core 6A, >8 cmbsf). Dotted line is line of best fit for the overlying sediments (open circles). Solid line is line of best fit for entire deeper core data set. Note: the two samples (red circles) with ladderane concentration suspected to be the result of sedimentary production (Core 6A) were not used to generate the lines of best fit or the coefficients of determination $\left(R^{2}\right)$ in the core sediments $(b)$. 

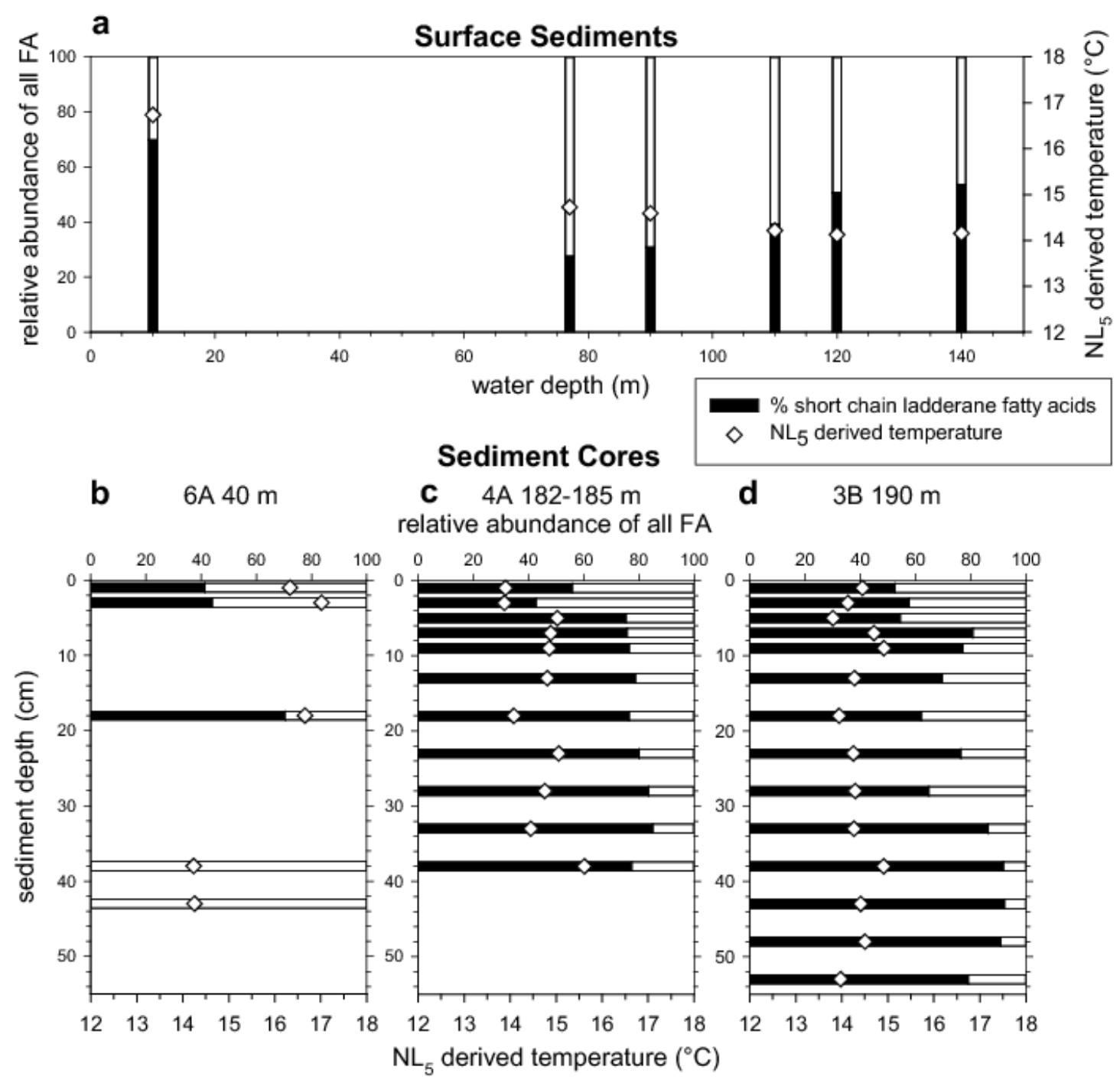

Figure 7: Vertical distribution of the proportion of short-chain ladderane fatty acids (black bars) and $\mathrm{NL}_{5}$ derived temperatures (open lozenges) in Golfo Dulce surface sediment (a) and sediment cores (b-d). 